Buca Eğitim Fakültesi Dergisi, 2021, Say1 51, s. 1-31

Araştırma Makalesi
The Journal of Buca Faculty of

Education, 2021, Issue 51, p. 1-31

Original Research

\title{
Probleme Dayalı Öğrenme Yönteminin Öğrencilerin Bilimsel Süreç Becerilerine Etkisi ${ }^{1}$
}

\section{The Effect of Problem Based Learning on Students' Scientific Process Skills}

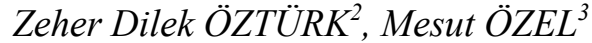

\begin{abstract}
${ }^{2}$ Doktora Öğrencisi, Matematik ve Fen Bilimleri Eğitimi Bölümü, Eğitim Bilimleri Enstitüsü, Pamukkale Üniversitesi, Türkiye, dilekkaraokutan@gmail.com, (https://orcid.org./0000-00025016-7787)

${ }^{3}$ Dr. Öğretim Üyesi, Matematik ve Fen Bilimleri Eğitimi Bölümü, Eğitim Fakültesi, Pamukkale Üniversitesi, Türkiye, mesutozel@outlook.com, (https://orcid.org/0000-0003-0672-7908)
\end{abstract}

Gelis tarihi: 08/04/2019

Kabul Tarihi:12/05/2021

ÖZ

Bu çalışmanın amacı, probleme dayalı öğrenme yönteminin ortaokul 7. sınıf öğrencilerinin bilimsel süreç becerilerine etkisini incelemektir. Çalışmada ön test-son test kontrol gruplu yarı deneysel desen kullanılmıştır. Araştırma, 2017-2018 eğitim-öğretim yılı 1. yarıyılında, Denizli il merkezinde bulunan bir devlet ortaokulunda gerçekleştirilmiştir. Çalışmada; deney grubu 30 kişi, kontrol grubu 27 kişi olmak üzere toplam 57 öğrenci yer almıştır. Çalışma 9 hafta sürmüştür. Deney grubunda, probleme dayalı öğrenme yöntemi kullanılmıştır. Kontrol grubunda ise Milli Eğitim Bakanlığı tarafından önerilen 2013 Fen Bilimleri Öğretim Programı'na göre ders yapılmıştır. Araştırmada, veri toplama aracı olarak; Aydoğdu, Tatar, Yıldız ve Buldur (2012) tarafından geliştirilen "Bilimsel Süreç Becerileri Testi" kullanılmıştır. Ön test ve son test verilerinin karşılaștırılmasında, bağımlı ve bağımsız gruplar t-testi analiz tekniklerinden yararlanılmıştır. Veriler SPSS 16.00 programı ile analiz edilmiştir. Araştırmanın sonucunda; deney grubu öğrencilerinin bilimsel süreç becerileri son test puanları ile kontrol grubu öğrencilerinin bilimsel süreç becerileri son test puanları arasında deney grubu lehine anlamlı farklılık bulunmuştur.

Anahtar sözcükler: Probleme dayalı öğrenme, bilimsel süreç becerileri, fen bilimleri dersi, kuvvet ve enerji.

\begin{abstract}
The aim of this study was to investigate the effectiveness of problem based learning on seventh grade students' scientific process skills. The pretest-posttest semi- experimental design with control group was used in the study. The study was implemented in a state middle school in Denizli, in the first semester of 2017-2018. In the study, 57 students were participated in the study group in all, including 30 students in the experimental group and 27 students in the control group. The study was lasted 9 weeks. The lessons were performed according to problem based learning in the experimental group, whereas in the control group the lessons were performed according to 2013 science course teaching program developed by Ministry of Education in Turkey. In the study, 'Scientific Process Skill Test' which was developed by
\end{abstract}

\footnotetext{
${ }^{1}$ Bu makale; birinci yazarın ikinci yazar danışmanlığında yürüttüğü "Fen Bilimleri Dersinde Probleme Dayalı Öğrenme Yönteminin Öğrencilerin Akademik Başarılarına ve Bilimsel Süreç Becerilerine Etkisi” isimli yüksek lisans tezinden üretilmiştir.
} 
Aydoğdu, Tatar, Yıldız and Buldur (2012) was used for data collection. Dependent paired-sample t-test and independent paired- sample t-test was used to compare pretests and posttests. In the analysis of data, SPSS 16.00 computer software was used. According to posttest scores obtained from the Scientific Process Skill Test, there is a significant difference between the experimental group and the control group in favor of the experimental group.

Keywords: Problem based learning, scientific process skills, science course, force and energy.

\section{GİRIŞ}

Her geçen gün hızla değiş̧en dünyamızın belirsizliği içinde, sürekli yığılan bilgi birikimini en verimli ve etkili biçimde kullanmak, yönetmek ve değerlendirmek önemli hâle gelmiştir. Gelecek günlerdeki yaşam, şimdiki hayal gücümüzün çok ötesinde olabilir. Günümüzdeki birçok meslek grubu ve iş alanının, bundan 5-10 sene sonra önemini ve geçerliliğini kaybedeceği ifade edilmektedir (Harari, 2018; OECD, 2018). Günümüzde yaşanan hızlı değişimler ve beraberinde getirdiği belirsizlik içinde, gelecek kuşakları yeniçağa en donanımlı şekilde hazırlamak amacıyla onlara rehberlik etmek oldukça güçtür. Böylesine bir belirsizlik içinde; sadece yerinde karar alabilen, problem çözme becerisine sahip, bilimsel süreç becerilerini etkili bir şekilde kullanabilen bir birey olmak yeterli değildir. Bu özelliklere sahip bireylerin yetiştirilmesini sağlamak da bir o kadar önemlidir. Bu sebeple; günümüzün koşulları içinde, ihtiyacı olan bilgiye ulaşabilmenin yollarını bilen, bu yolları etkin bir biçimde kullanabilen, eleştirel düşünme becerisine sahip, etkili kararlar alabilen bireylerin yetiştirilmesi daha da önem kazanmıştır. Günümüz bireylerinin, yaşanmakta olan değişimleri ve yenilikleri kavrayabilen, içinde bulunduğu ortama en iyi şekilde uyum sağlama becerisine sahip, esnek düşünme becerileri ile donanmış olmaları da ayrıca önemlidir. Ayrıca bu bireylerin ekip çalışmasına ve işbirliğine yatkın olmaları kadar sahip oldukları iletişim becerilerini etkin bir biçimde kullanabilmeleri gerekmektedir (Ananiadou ve Claro, 2009; Ergin, Şahin ve Öngel, 2005; Gray, 2016; Shaw, 2008; OECD, 2018; Partnership for 21st Century Skills (P21), 2003; 2015; Trilling ve Fadel, 2009; Wagner 2008 ).

Eğitim de içinde bulunduğumuz bu hızlı değişim ve dönüşümden etkilenmektedir. $\mathrm{Bu}$ sebeple ülkeler, eğitim sistemlerini gözden geçirme gerekliliği duyarak, bu alanda köklü reformlara gitmişlerdir. Neticede, davranışçı öğretim yaklaşımları terk edilerek, öğrencinin yani öğrenenin, öğrenmenin odağında bulunan aktif öğrenmeye dayalı yaklaşımlar benimsenmeye başlanmıştır. Var olan ihtiyaçlar doğrultusunda geliştirilen öğretim programları; bilgi edinme yollarını kullanabilen, elde ettiği bilgiyi sorgulayan, üst düzey düşünme becerilerine sahip bireylerin yetiştirilmesini amaçlamaktadır. Ayrıca bireylerin sahip olmaları beklenen bu becerileri etkin bir biçimde kullanarak karşılaştığ sorunların üstesinden gelebilen, yaşam boyu öğrenen kişiler olmaları hedeflenmektedir (National Research Council (NRC), 1996; Milli Eğitim Bakanlığı, 2013; MEB, 2015; MEB, 2018). Günümüz koşulları da dikkate alındığında, fen bilimleri derslerinin ne kadar gerekli ve önemli olduğu ön plana çıkmaktadır. Glasser (1993) 21. yüzyıl bireyinin; bilgiyi üreten kimse olması gerekliliğine değinmiştir. '21. Yüzyıl Öğrenme Çerçevesi'nde (Framework for 21st Century Learning) (2017) günümüz bireyinin sahip olmas1 gereken beceriler arasında; eleştirel düşünme (etkili akıl yürütme becerileri, sistemli düşünme, analiz etme ve etkili karar alma becerileri), problem çözme, yaratıcı düşünme ve girişimcilik becerileri ile işbirliğine dayalı becerilerinin yer aldığı görülmektedir (21st Century Student Out comes and Support Systems, 2017).

21. yüzyıl öğrenme çerçevesi göz önünde bulundurularak, ülkemizde 2018 Ortaokul Fen Bilimleri dersi öğretim programı oluşturulmuştur. Yenilenen 2018 Ortaokul Fen Bilimleri dersi öğretim programı alana özgü beceriler arasında; bilimsel süreç becerileri, yaşam becerileri (analitik düşünme, karar verme, yaratıcılık, girişimcilik, iletişim, takım çalışması) ile mühendislik ve tasarım becerilerinin yer aldığı görülmektedir (MEB, 2018). 21. yüzyıl öğrencileri; kendi öğrenme sorumluluklarını alabilme becerilerine sahip, yaşam boyu öğrenen bireyler olmalıdır. $\mathrm{Bu}$ amaç doğrultusunda; okullarda, öğrencilere, gündelik yaşamda 
karşılaşabilecekleri gerçek yaşam problemlerini çözebilmelerini sağlamak amacıyla problem çözme becerilerinin kazandırılması gereklidir. John Dewey de benzer şekilde (1916); eğitim kurumlarının, yaşamın kendisi olmaları gerektiğini vurgulamıştır. Günlük yaşamımız içinde karşılaşılan yeni bir durumla ilgili ortaya çıkan problemi çözebilme, bilimsel süreç becerileri ile gerçekleştirilebilir (Kaptan ve Korkmaz, 2001). Öğrenme; öğrencilerin iyi yapılandırılmış sorulara verdikleri doğru yantlar değildir. Öğrencilerin kendi öğrenme süreçlerini yapılandırarak öğrenme sürecini bizzat kendilerinin yönetmesidir. Bu nedenle asıl amaçlanan; öğrencilerin, günlük yaşam problemlerini çözebilmeleri için gerekli yeterlilikleri ve becerileri kazanabilmelerini sağlamak olmalıdır. Öğrencilerin etkili karar alabilmeleri için onların aktif birer problem çözücü olmaları gereklidir (Lee \& Bae, 2008; Woods, 1985). Gündelik hayatta karşılaşılan problemleri çözebilmeyi öğrenmek, bilimsel süreç becerilerinin ne kadar etkili kullanıldığına bağlı olarak değişmektedir (Aktamış ve Ergin, 2007; NRC, 1996; NRC, 2011; 21 st Century Student Outcomes and Support Systems, 2017; Framework for 21st Century Learning, 2017).

Fen derslerinde, bilimsel bilgiyi öğretmekten ziyade bilimsel bilgiye ulaşma yollarının öğrencilere kazandırılması gereklidir (Şenyüz, 2008). Bu sebeple ülkemizde uygulanmakta olan Ortaokul Fen Bilimleri Öğretim Programı, farklı bireysel özelliklere sahip tüm öğrencilerin fen okuryazarı olması gerekliliğini vurgulamaktadır (MEB, 2013; MEB, 2018). Fen okuryazarı olan bir birey; araştıran-sorgulayan, eleştirel düşünme becerilerine sahip, günlük hayatla fen konuları arasında bağlantı kurabilen, karşılaştığı problemlerin çözümü aşamasında bir bilim insanı gibi bilimsel süreç becerilerini ve karar verme mekanizmalarını kullanabilen, yaşam boyu öğrenme becerisini edinmiş, çevresine ve dünyaya meraklı gözlerle bakan kişidir (MEB, 2013:1). Bu bireyler; doğru bilgiye ulaşma yolarını bilen ve bu bilgiyi karşılaştığı problemlerin çözümünde ya da etkili karar almakta kullanabilme becerisine sahip kişilerdir (MEB, 2015). Günlük yaşantıları içinde karşılaştıkları problemleri tanımlayabilme ve var olan problemin çözümüne uygun hipotezler geliştirerek çözüme ulaşma sürecinde bilimsel araştırma sürecini takip edebilirler (Liang, 2002). Bu nedenle fen öğrenmek demek; aslında araştırma yol ve yöntemlerini öğrenmek yani bilimsel süreç becerilerini ve bu becerilerin kullanımını öğrenmektir (Tan ve Temiz, 2003).

Alan yazın incelendiğinde bilimsel süreç becerileri ile ilgili birçok tanımın bulunduğu göze çarpmaktadır (Arslan ve Tertemiz, 2004; Ergin ve diğ., 2005; Ostlund, 1995; Padilla ve Okey 1984; Tan ve Temiz, 2003). Şahin-Pekmez (2000), bilimsel süreç becerilerini; öğrenmeye yardım eden, öğrenciye keşfetme yöntemlerini öğreten, öğrenenin aktif olduğu, onların sorumluluklarını geliştiren ve laboratuvar çalışmalarını anlamalarında onlara yardımcı olan temel beceriler olarak tanımlamaktadır. Çepni, Ayas, Johnson ve Turgut'a göre (1997), bilimsel süreç becerileri; bilimsel araştırma yolları ile yöntemlerini içeren temel becerilerdir. Bilimsel süreç becerilerinin, fen bilimleri dersinde öğrenme üzerindeki kolaylaştırıcı rolü, öğrenme sürecine öğrencinin aktif katılımındaki payı, öğrenme sorumluluğu ile öz düzenleme becerilerine katkı sağlayarak öğrenmenin kalıcılığını arttırdığını ifade etmişlerdir.

Ülkemizde eğitim alanında yapılan reform neticesinde 2005 y1lında yapılandırmac1 yaklaşım benimsenerek öğrenci, öğrenmenin merkezine alınmıştır. Takiben, hem 2013 ve hem de 2018 yılı Fen Bilimleri Dersi Öğretim Programları'nda araştırma-sorgulamaya dayalı öğrenme stratejisinin benimsenerek probleme dayalı öğrenmeye vurgu yapıldığı görülmektedir. Bu durumun doğal bir sonucu olarak, ulusal alan yazında, PDÖ’nün eğitimin farklı alanlarında ve düzeylerindeki uygulamalarına yönelik çalışmalar giderek artmıştır. Fen Bilimleri Dersi Öğretim Programı'nda kazandırılmak istenen kazanım ve beceriler kıyaslandığında, Fen Bilimleri Programı ile probleme dayalı öğrenme yöntemi arasındaki ilişki net bir biçimde göze çarpmaktadır (Can, Gencer, Yıldırım ve Bahtiyar, 2016). Bu amaç doğrultusunda probleme dayalı öğrenme senaryolarını içeren uygulamalar ile bilimsel süreç becerilerinin kazandırılması ve bu becerilerin geliştirilmesi önem kazanmaktadır. Gerek 2005, 2013 gerekse de 2018 Fen Bilimleri Öğretim Programları vizyonu, tüm öğrencilerin birer fen okuryazarı olarak 
yetiştirilmesinin önemini belirtmektedir. Her bir öğretim programında da fen okuryazarlığına ait bir boyut olarak bilimsel süreç becerilerine değinilmiştir (MEB, 2006; MEB, 2013; MEB, 2018). Bilimsel süreç becerileri; araştırma, sorgulama, deney yapma, veri kaydetme, değerlendirme ve sonuç çıkarma becerilerinden oluşmaktadır (Zimmerman, 2007). 2018 Fen Bilimleri Dersi Öğretim Programı'nda 'alana özgü beceri' öğrenme alanının kapsadığ 1 alt boyutlardan biri "bilimsel süreç becerileri" dir. Bilimsel süreç becerileri; gözlem yapmayı, ölçmeyi, sınıflamayı, veri kaydetmeyi, hipotez kurmayı, veri kullanmayı ve model oluşturmayı, değişkenleri değiştirmeyi ve kontrol etmeyi, deney yapmayı kısacası bilim insanlarının çalışmalarında kullandıkları temel becerileri içermektedir (MEB, 2018: 9). Bilimsel süreç becerilerinin öğrenme ortamlarına aktarılmasıyla öğrenciler, merak ettikleri olayları ve çevrelerinde olan biteni anlamak için araştırma yapma imkânına kavuşurlar. Bu sayede bilimsel bilginin ne olduğunu ve nasıl geliştiğini kendi yaşantıları yoluyla deneyimleyerek ve anlamlandırarak öğrenebilirler.

Şu anda ülkemizde uygulanmakta olan 2018 Fen Bilimleri Dersi Öğretim Programı, disiplinler arası bir bakış açısı ile araştırma-sorgulamaya dayalı öğrenme yaklaşımını temel almıştır. Programda, bilginin yeni durum ve koşullara uyarlanabilmesine dayalı öğrenme yöntem ve stratejilerine dikkat çekilmektedir. Araştırma-sorgulama stratejisine dayanan yöntemler arasında; işbirliğine dayalı öğrenme, probleme dayalı öğrenme, proje temelli öğrenme ve argümantasyona dayalı öğrenme yer almaktadır (MEB, 2018). Programda vurgulanan yöntem ve stratejiler, öğrencinin merkeze alındığı öğrenme ortamlarında derslerin yürütülmesini öngörmektedir. Bu amaçla kullanılan yöntemlerden birisi de öğrenciyi merkeze alan Probleme Dayalı Öğrenme (PDÖ) yöntemidir (MEB, 2018). PDÖ’nün temelleri, John Dewey'(1938) in 'yaparak yaşayarak öğrenme' görüşüne dayanmaktadır. PDÖ, temeli tıp fakültelerinde atılan bir öğretim yöntemi olarak alan yazına geçmiştir (Barrows ve Tamblyn, 1980; Boud, 1985). Buna karşın sürekli değişen dünyanın ihtiyaçları ile problemlerine çözüm bulabilen, değişime ayak uydurabilen bireyler yetiştirebilmek amacıyla farklı disiplinler içinde de yer almıştır (Duch, Groh ve Allen 2001). Bu durumun gerekçelerinden biri olarak; bireyden beklenen, yaşadığ 1 toplum içinde karşılaştığ aynı zamanda sahip olduğu yeterlilikleri ve becerileri doğrultusunda karşılaştığı bu problemleri çözümleyebilme ihtiyacı öne sürülebilir.

Probleme dayalı öğrenme (PDÖ); bilginin yapılandırılması sürecinde öğrencinin bizzat aktif olduğu, ön bilgilerini dikkate alarak, gerçek yaşam problemlerini çözüme ulaştırmak için gerek grupla ve gerekse bireysel araştırmaların yapıldığı, etkili iletişimin becerilerinin kullanıldığı, yaşam boyu öğrenmeyi destekleyen bir öğretim yöntemidir (Akınoğlu ve Özkardeş-Tandoğan, 2007; Boud ve Feletti, 1991; Demirel ve Arslan Turan, 2010; Duch ve diğ. 2001; Hmelo-Silver, 2004; Torp ve Sage, 1998; Peterson ve Treagust, 1998; Şenocak ve Taşkesengil, 2005; Taşkesengil, Şenocak ve Sözbilir, 2008). PDÖ'de öğrenciler, öz denetimli öğrenme ile edindikleri yeni bilgiyi karşılaştıkları probleme uygularlar. Problemin çözümü sürecinde ne öğrendiklerini yansitırlar (Tüysüz, Tatar ve Kuşdemir, 2010). PDÖ’nün amaçları arasında; öğrencilerin bilgi edinme becerileri, edindikleri bilgiyi transfer edebilmeleri, etkili problem çözme becerisi kazanmaları yer almaktadır. Ayrıca PDÖ öğrencilerin, kendi kendine öğrenme becerilerini ve içsel motivasyonlarını geliştirmelerine olanak sağlar (Hmelo-Silver, 2004). Bunun yanı sıra PDÖ süresince; analiz etme, sentez yapma ile değerlendirme gibi üst düzey bilişsel becerileri kazanırlar (Tatar, 2007). Öğrencilerin, gerçek hayatta karşılaşabilecekleri problemler ile önceden yüz yüze gelmelerini sağlayarak, onların karşılaştıkları veya karşılaşabilecekleri sorunlar ile başa çıkabilme becerilerini geliștirmek PDÖ'nün en önemli amaçlarından birisidir (Kaptan ve Korkmaz, 2001; Açıkgöz, 2003). PDÖ, aynı zamanda öğrenenin bilimsel süreç becerilerini işe koşmasına imkân sağlayan bir öğrenme yöntemidir (Tosun, Şenocak ve Özeken, 2013).

PDÖ ile ilgili hem ulusal hem de uluslararası alan yazında eğitim alanının farklı disiplinlerine, öğretim kademelerine, sınıf düzeylerine, konu alanlarına ve öğrenme ürünlerine 
yönelik araştırmaların yapıldığı bilinmektedir (Alacapınar ve Ok, 2020; Ayaz, 2015; Dağyar, 2014; Gijbels, Dochy, Van den Bossche ve Segers, 2005). Bunlar arasında; öz yeterlik ve tutum (Rajab, 2007), öğretmen adaylarına yönelik PDÖ uygulamalar (Goodnough, 2011), öğretmenlere yönelik yapılan PDÖ uygulamaları (Pecore, 2012), PDÖ'nün öğrencilerin özdüzenleme becerilerine (Arslan-Turan, 2014; Chen ve Lord, 2013; Stefanou, Stolk, Prince,), akademik başarılarına (Dağyar, 2014; Demirel, 2014; Dobbs, 2008; İnel, 2009; Karaca, 2014; Keleş, 2015; Tüysüz, Tatar ve Kuşdemir, 2010; Yılmaz, 2016), işbirlikli çalışmaya etkisi (Chin ve Chia, 2004), kavramsal anlama düzeyleri (Yurick, 2011; Wirkala ve Kuhn, 2011) problem çözme becerileri (Kuo, Hwang ve Lee, 2012) ile yaratıcılıkları (Kanar, 2017), akademik başarı ve karar verme becerileri üzerine (Tetik, 2013), üst düzey düşünme becerileri üzerine (Çınar ve İlik, 2013), akademik başarı ile tutuma (Ayaz, 2015; Elbistanl1, 2012; Hun, 2017; Yıldız, 2017) motivasyona (Kuşdemir, 2010; Moralar, 2012), kavramları yapılandırma düzeyleri ile sorgulayıc1 öğrenme becerilerine (İnel, 2009), biliş ötesi farkındalık ve güdü düzeylerine (Demirel ve Arslan Turan, 2010) bilimsel süreç becerilerine (Büyükdokumacı, 2012; Demirel, 2014; Elbistanl1, 2012; Myers, 2004; Pakyürek Karaöz, 2008; Serin, 2009; Söyleyici, 2018; Taşoğlu, 2009; Urtekin, 2012; Zeidan ve Jayosi, 2015), kavram karikatürleri destekli PDÖ'nün problem çözme becerileri ile kavramsal anlama düzeyleri üzerine (İnel, 2012), analitik düşünme becerileri ile kavramsal anlamalarına (Olça, 2015), çevre farkındalığı ile çevre bilgisine (Dursun, 2015), eleştirel düşünme becerilerine (Yalçınyiğit, 2016), multimedya destekli PDÖ uygulamasının öğrenme ürünlerine etkisine (Divarcı, 2016), otantik PDÖ etkinliklerinin yansıtıcı düşünme becerisi, akademik başarı, çevre tutumu ile farkındalıklarına (Dadl1, 2017), argümantasyon destekli probleme dayalı öğrenmenin sorgulayıcı öğrenme becerisine (Yıldırım ve Can, 2017), PDÖ'de öz ve akran değerlendirme uygulamaları (Güzel, 2018) üzerinde olumlu etkilerinin bulunduğu birçok çalışmanın yer aldığı göze çarpmaktadır. Bununla birlikte, yürütülen bazı araştırmalarda PDÖ uygulamalarının anlamlı fark yaratmadığı araştırma sonuçları da bulunmaktadır (İpek, 2004; Serin, 2009; Yıldız, 2010). Yakın zamanda yurtiçinde, fen eğitimi alanında yapılan PDÖ çalışmaları arasında, yukarıda verilen örneklerden farklı olarak; eğitsel robotik uygulamalarla yapılan PDÖ uygulamaları (Tatlısu, 2020), PDÖ destekli

STEM uygulamaları (Aysu, 2019), sanal öğrenme ortamlarında uygulanan PDÖ uygulamalarının (Aktı Aslan, 2019) etkilerini belirlemeye yönelik çalışmaların yapıldığ belirlenmiştir. Bu çalışmalar neticesinde; PDÖ uygulamalarının, öğrencilerin problem çözme becerilerine, akademik başarılarına, bilgi kalıcılığı ile motivasyonları üzerinde olumlu etkileri olduğu sonucuna ulaşılmıştır.

Bunun yanı sıra ulusal alan yazın incelendiğinde, son y1llarda PDÖ uygulamalarının belirli bir konu veya ünite üzerinde çalışıldığı süreç odaklı uygulamaya dayalı olarak yürütüldüğü görülmektedir. Aynı zamanda belli bir ünite ya da belirlenmiş bir konu süresince bilimsel süreç becerilerinin PDÖ uygulamaları ile kazandırılması ve geliştirilmesinin araştırmalara konu olduğu ve yaygınlaştığı göze çarpmaktadır. "Kuvvet ve Hareket/Enerji" ünitesi kapsamında yurtiçinde, ortaokul seviyesindeki PDÖ çalışmaları incelendiğinde; öğrenme ürünlerine (Yaman, 2003), akademik başarı ile kavramsal öğrenmeye (Özkardeş-Tandoğan, 2006), bilimsel süreç becerilerine, akademik başarıya (Şencan, 2013) ve tutuma (Serin, 2009; Pakyürek-Karaöz, 2008), kavramları yapılandırma düzeyleri, akademik başarıları ile sorgulama becerilerine (İnel, 2009), problem çözme beceri algılarına ve kavramsal anlama düzeylerine (İnel, 2012), akademik başarı, öz düzenleme becerileri ve akademik özgüvene (Arslan-Turan, 2014), akademik başarı ve tutuma (Aysu, 2019; Aktı Aslan, 2019; Divarc1, 2016; Kartal Taşoğlu, 2009; Yıldırım, 2011; Yıldız, 2017) yönelik çalışmaların yapıldığı göze çarpmaktadır. Örneğin; Aysu (2019) çalışmasında, 6. sınıf fen bilimleri dersinde "Kuvvet ve Hareket" ünitesi kapsamında STEM etkinlikleri ile desteklenen PDÖ uygulamasının akademik başarı ile bilgi kalıcılığına etkisini araştırmıştır. Yarı deneysel olarak yapılan çalışma sonucunda, deney grubunda uygulanan STEM destekli PDÖ uygulamasının akademik başarı ile bilgi kalıcılığını arttırdığg sonucuna ulaşılmıştır. Benzer olarak; Aktı Aslan (2019)'ın çalışmasında, 7. sınıf "Kuvvet ve Enerji" ünitesi kapsamında PDÖ temelli tasarlanan sanal öğrenme ortamlarının, 
akademik başarı, problem çözme becerileri ile motivasyona etkisini araştırmıştır. Karma yöntemin uygulandığı araştırmada, sanal öğrenme ortamları ile desteklenen PDÖ uygulamasının, öğrencilerin akademik başarı ile problem çözme becerileri üzerinde olumlu katkısı olduğu sonucuna varılmıştır.

Ulusal alan yazın incelendiğinde; "Kuvvet ve Enerjisi" ünitesi ile ilgili bilimsel araştırma yöntemi basamaklarına dayalı senaryo çalışma yaprakları ile PDÖ yönteminin kullanıldığı bir çalışmaya rastlanmamıştır. Bu nedenle yapılan bu araştırma, 7. Sınıf Fen bilimleri dersi "Kuvvet ve Enerji" ünitesinde kullanılan PDÖ uygulamasının bilimsel süreç becerilerine etkisini açığa çıkarmayı amaçlayan örnek bir çalışmadır. "Kuvvet ve Enerji” ünitesi, öğrencilerin hem bireysel hem de işbirliğine dayalı olarak çalışabilmelerine elverişlidir. Ünite, öğrencilerin uygulamalı etkinlikler yapabilecekleri ve bilimsel araştırma basamaklarını etkin olarak kullanabilecekleri konulardan oluşmaktadır. Ayrıca, bu çalışma "Kuvvet ve Enerji" ünitesinde yer alan tüm kazanımları kapsamaktadır. Bunun yanı sıra, çalışmada kullanılan senaryo çalışma yaprakları bilimsel araştırma yöntemi basamaklarını içermesi dolayısıyla alan yazında var olan PDÖ çalışmalarından ayrılmaktadır. Belirtilen sebepler göz önüne alındığında, yapılan bu çalışmanın alan yazın ile birlikte eğitim sistemine de katkı sağlayacağı düşünülmektedir.

$\mathrm{Bu}$ çalışmanın amacı, ortaokul 7. sınıf fen bilimleri dersi "Kuvvet ve Enerji" ünitesinin öğretiminde kullanılan senaryolarla probleme dayalı öğrenme yönteminin, öğrencilerin bilimsel süreç becerilerine etkisi incelemektir. Bu amaca dayalı olarak araştırmanın alt problemleri;

1. Deney grubu ile kontrol grubunu oluşturan öğrencilerinin bilimsel süreç becerileri ön test puan ortalamaları arasında anlamlı bir fark var midır?

2. Deney grubu ile kontrol grubunu oluşturan öğrencilerinin bilimsel süreç becerileri son test puan ortalamaları arasında anlamlı bir fark var midır?

3. Kontrol grubunu oluşturan öğrencilerin bilimsel süreç becerileri ön test puan ortalamaları ile son test puan ortalamaları arasında anlamlı bir fark var midır?

4. Deney grubunu oluşturan öğrencilerin bilimsel süreç becerileri ön test ve son test puan ortalamaları arasinda anlamlı bir fark var midir?

şeklinde belirlenmiştir.

\section{YÖNTEM}

\subsection{Araştırmanın Modeli}

$\mathrm{Bu}$ araştırma, yarı deneysel bir model olan eşitlenmemiş ön test-son test kontrol grubuna dayalı olarak yürütülmüştür. Yarı deneysel desenlerde hâli hazırda var olan gruplardan ikisi, belli değişkenler üzerinden eşleştirilir. Eşleştirilmesi yapılan gruplar, işlem gruplarına rastgele olarak atanır (Büyüköztürk, Çakmak, Akgün, Karadeniz ve Demirel, 2014). Yapılan bu çalışmada; eğitim-öğretim yılı başında okul idaresinin belirlemiş olduğu şubelerden biri deney grubu, bir başkası kontrol grubu olarak seçilmiştir. Yarı deneysel yöntem ile; deney ve kontrol gruplarında uygulanan ön test ve son testler sonucunda elde edilen veriler istatistiksel işlemlere tabi tutulur. Uygulanan istatistik işlemler ile deney ve kontrol gruplarının arasında anlamlı bir farkın olup olmadığı ortaya çıkarılmaya çalışılır (Çepni, 2016). Araştırmalarda, deneysel desenin tercih edilmesinin en temel gerekçesi; yeni bir program, yeni bir öğretim yöntemi gibi herhangi bir değişkenin etkililiğini ölçmektir. Deneysel desenler ile yapılan ölçüm sonucunda açığa çıkan bulgular dikkate alınarak çeşitli öneriler öne sürülür (Ekiz, 2009).

Deneysel uygulamaya alınan gruplar içinde etkisi incelenen bağımsız değişken; probleme dayalı öğrenme ortamıdır. Araştırmanın bağımlı değişkeni ise bilimsel süreç becerileridir. Fen bilimleri dersleri kontrol grubunda; araştırma süresince "Kuvvet ve Enerji" ünitesi kapsamında, MEB tarafından okullara dağıtılan kitapların etkinlikleri takip edilerek işlenmiştir. Deney grubunda ise "Kuvvet ve Enerji" ünitesi süresince; bilimsel araştırma yöntemi basamaklarına 
dayalı senaryo çalışma yaprakları doğrultusunda PDÖ yöntemi kullanılmıştır. Çalışma, bir deney grubu ile bir kontrol grubu üzerinden gerçekleştirilmiştir. Araştırma boyunca hem deney grubu hem de kontrol grubunda işlenen dersler, 14 yıllık fen bilimleri öğretmenliği tecrübesine sahip aynı ögretmen tarafından yürütülmüştür.

\subsection{Araştırmanın Çalışma Grubu}

Deneysel araştırmalarda evren ve örneklem seçimi yerine çalışma grubunun alınması tercih edilmelidir (Sönmez, 2005). Araştırmanın çalışma grubu; 2017-2018 eğitim-öğretim yılında Denizli ili Pamukkale ilçesinde bir devlet okulunda (Merkez Ortaokulu) öğrenim gören 57 kişiden oluşan 7. Sınıf öğrencilerinden oluşmaktadır. Araştırma için bu okulun tercih edilmesinin sebebi, araştırmacının adı geçen okulda görev yapıyor olmasıdır. Bu sayede, uygulamaların gerçekleştirilmesi ile veri toplama sürecinin sağlıklı bir şekilde yürütülmesinde karşılaşılabilecek sorunların en aza indirgenmesi amaçlanmıştır. Araştırmanın gerçekleştirildiği okulda bulunan on beș 7'nci sınıf şubesi arasından rastgele belirlenen iki şubeden biri deney grubu, bir diğeri ise kontrol grubu olarak atanmıştır. Çalışma, 2017-2018 eğitim öğretim yılı 1. dönemi içinde yapılmıştır. Çalışmanın deney grubu 30 (16 kı, 14 erkek) ve kontrol grubu 27 (12 kız, 15 erkek) öğrenciden oluşmaktadır. Uygulama 9 hafta ve 36 ders saati sürmüş̧tür.

\subsection{Araştırmacının Rolü}

Araştırma boyunca hem deney grubundaki hem de kontrol grubundaki dersler, 14 y1llık fen bilimleri öğretmenliği tecrübesine sahip araştırmacı rolünü üstlenen öğretmen tarafindan yürütülmüştür. Araştırmacı olan öğretmen, PDÖ uygulama süreci hakkında bilgi edinmek için PDÖ yönteminin uygulandığı Pamukkale Üniversitesi Eğitim Fakültesi Fen Bilgisi Öğretmenliği 3. Sınıf öğrencilerine yönelik Fen Öğretimi Laboratuvar Uygulamaları-II derslerine gözlemci olarak katılmıștır. Dört hafta süresince konuk olduğu derslerde, eğitim yönlendiricisinden, PDÖ yöntemini, kullanılan senaryoların sahip olması gereken temel özellikleri, çalışma gruplarının oluşturulmasını, işleyişini, grup içi rol paylaşımı ile etkileşimini, grupların senaryo üzerinde yaptıkları çalışmaları, problem çözümünde takip edilen işlem basamaklarını ve gruplarda ulaşılan sonuçların nasıl sunulduğunu deneyimleyerek öğrenmiştir. Aynı süre içinde PDÖ yöntemi ve uygulanışı ile ayrıca PDÖ senaryolarının yazımı hakkında alan yazın taraması yapmışıtır. Araştırmada kullanılacak olan senaryoları hazırlamıştır. Senaryo yazımlarının ardından; alan uzmanı öğretim görevlisi (2 kişi), fen bilimleri öğretmeni (2 kişi) ile Türkçe öğretmeni (1 kişi) nin görüşleri alınmıştır. Alınan görüşlerin neticesinde senaryolar üzerinde gerekli düzenlemeler ve değişiklikler yapılmıştır.

Hazırlanan senaryoların ön uygulaması, 2016-2017 eğitim-öğretim yılı ikinci dönemi içinde, Denizli il merkezinde bulunan bir devlet okulunun 7. sinıf öğrencileri ile gerçekleștirilmiștir. Ön uygulama 9 hafta sürmüștür. Hazırlanan ve uygulanan senaryolarda aksayan yönler belirlenmiştir. Böylelikle, hazırlanan senaryoların uygun şekilde çalışıp çalışmadığı sınanmıştır. Ayrıca senaryolarda, öğrencilerden alınan görüşler doğrultusunda gerekli düzenlemeler ve iyileştirmeler gerçekleştirilmiştir.

\subsection{Veri Toplama Aracı}

Araştırmanın veri toplama aracı "Bilimsel Süreç Becerileri Testi" (BSBT) dir. Araştırma süresince deney ve kontrol gruplarının derslerine araştırmacı girmiştir. Araştırmada deney ve kontrol grubunda uygulanan testlere dayalı veriler, araștırmacı ile birlikte bir başka gözetmen öğretmenin eşliğinde toplanmıştır. Araştırmada kullanılan "Bilimsel Süreç Becerileri Testi" (BSBT); Aydoğdu, Tatar, Yıldız ve Buldur (2012) tarafından geliştirilmiştir.

\subsubsection{Bilimsel Süreç Becerileri Testi (BSBT)}

Aydoğdu, Tatar, Yıldız ve Buldur (2012) tarafından geliştirilen "Bilimsel Süreç Becerileri Testi", ilköğretim 6, 7 ve 8 . öğrencilerinin bilimsel süreç becerilerini ölçmek amacıyla geliştirilmiştir. Bilimsel süreç becerileri ölçeği pilot uygulamasında 34 adet çoktan seçmeli soru yer almaktadır. Ölçeğin iç geçerliliğinin ortaya konması amaciyla gerekli uzman 
görüşlerine başvurulmuştur ( 2 fen ve teknoloji öğretmeni ve 3 fen eğitimi öğretim üyesi). Uzman görüșleri neticesinde anlașılması güç olan 6 soru ölçekten çıkarılmıștır. Bunun sonucunda 28 maddelik "Bilimsel Süreç Beceri Testi" (BSBT) oluşturulmuştur. 28 maddelik testin pilot çalışması 6,7 ve 8 . Sınıf öğrencilerinin oluşturduğu 345 kişilik gruba uygulanmıştır. Yapılan madde analizi neticesinde 27 sorudan oluşan asıl test oluşturulmuştur. 27 soruluk Bilimsel Süreç Beceri Testi'nin KR-20 güvenirlik katsayısı 0,84; ortalama güçlüğü 0,54 olarak hesaplanmıştır. Bilimsel Süreç Becerileri Testi; 9 temel beceriyi, 18 üst düzey beceriyi ölçen 27 adet sorudan oluşmaktadır.

\subsubsection{Araştırmada Kullanılan PDÖ Senaryoları}

Araştırmada deney grubu için Fen Bilimleri Öğretim Programı 7. Sınıf "Kuvvet ve Enerji" ünitesi kazanımları (Ek-l) dikkate alınarak gerçek yaşam durumları ile sorunlarını içeren PDÖ senaryoları düzenlenmiştir. Bilimsel araştırma yöntem basamaklarına dayanan senaryo çalışma yapraklarının hazırlanma sürecinde; Can, Gencer Savran, Bahtiyar, Yıldırım (2016) ile Serin (2009)'den yararlanılmıştır. Gerçek hayat sorunlarının dikkate alındığı senaryoların yazımı araştırmacı tarafından gerçekleştirilmiştir. Yazılan her bir senaryo örneğinin tek bir kazanım ile problem durumunu içermesine özen gösterilmiştir. Senaryoların metin yazımı sırasında Ortaokul Fen Bilimleri Öğretim Programı (MEB, 2013) 7.sınıf "Kuvvet ve Enerji” ünitesindeki kazanımlar doğrultusunda; MEB tarafından dağıtılan ders kitabı, yardımcı kaynaklar, bilimsel yayın (dergi, kitap), güncel olay (gazete haberleri) ve çeşitli internet kaynakları kullanılmıştır. Yazılan metinler ile ilgili olarak, iki fen bilimleri öğretmeninin, iki öğretim üyesinin ve bir Türkçe öğretmeninin görüşlerine sunulmuştur. Belirtilen öneriler neticesinde senaryo metinleri üzerinde gereken düzenlemeler ile iyileştirmeler yapılmıştır.

Deney grubunda uygulanmak üzere "Kuvvet ve Enerji" ünitesinin kapsamında 13 tane senaryo metni hazırlanmıştır. Senaryoların hazırlanmasında gündelik yaşamda karşılaşılan, öğrencilerde merak uyandırıcı ve dikkat çekici durumlar ifade edilmiştir. Senaryo metinlerinde yer alan problem durumlarının, öğrenciler tarafından anlaşllabilecek biçimde net ve basit bir dille ifade edilmesine dikkate edilmiştir. Senaryo metinlerini takiben öğrencilerin senaryo metininde yer alan problemi tanımlamalarına yardımcı olacak bir ya da birkaç soru bulunmaktadır. $\mathrm{Bu}$ soruların rehberliğinde öğrencilere, senaryo metni içindeki problem durumunu tespit edebilmeleri amaçlanmıştır. Ayrıca tespit edilen problem durumunun çözümü amacıyla gerekli basamak ve işlemlerin öğrenciler tarafından ortaya çıkarılması hedeflenmiştir. Tasarlanan senaryo çalışma kâğıtlarının her birinde; bilimsel araştırma yöntem basamaklarının kullanılmasının amaçlandığı açık uçlu sorular bulunmaktadır. Çalışma kâğıtlarının, senaryonun konusuna uygun görsel unsurlar ile desteklenmesine özen gösterilmiştir. Buradaki amaç; öğrencinin dikkatini çekerek senaryolara yönelik merak uyandırmaktır.

Hazırlanan senaryo çalışma kâğıtlarının pilot çalışması, araştırmacı tarafından 2016-2017 eğitim-öğretim yılı 2. dönemi içinde gerçekleştirilmiştir. Ön uygulama süresince öğrencilerin anlamakta güçlük çektiği bölümler belirlenerek öğrencilerin görüşleri doğrultusunda gerekli düzenlemeler yapılmış, senaryolara son şekilleri verilmiştir. Araştırmada deney grubunun kullandı̆̆ problem senaryolarının "Kuvvet ve Enerji" ünitesi kazanımları ile ilgili kazanımların konu/kavram ilişkisi Ek-1'de verilmiştir.

Araştırma süresince kullanılan bilimsel araştırma yöntemi basamaklarının kullanıldığı senaryo çalışma yaprakları, rehberli sorgulayıcı-araştırmaya dayalı olarak tasarlanmıştır. Senaryo çalışma yapraklarına ait bir örnek Ek 2'de verilmiştir. Rehberli sorgulayıc1-araştırmada öğretmenin rolü; öğrenciyi, bir araştırma konusuna veya soruna (probleme) yönlendirmektir. Öğrenci, problemi çözebilmek amacıyla nasıl bir bilgiye ihtiyacı olduğunu ve bu bilgiye nereden, nasıl ulaşacağına kendisi karar verir (Köseoğlu ve Tümay, 2013). 


\section{5. İșlem}

Araştırmacı tarafından hazırlanan senaryo metinlerinin yazımının ardından, iki fen bilimleri öğretmeni, iki alan uzmanı öğretim görevlisi ve bir Türkçe öğretmeninin görüşlerine başvurulmuştur. Öneriler neticesinde senaryo metinlerinde çeşitli iyileştirmeler ve değişiklikler yapılmıştır. Hazırlanan senaryolar, bilimsel araştırma yöntem basamaklarının yer aldığı çalışma kâğıtları biçiminde düzenlenmiştir. Çalışma kâğıtlarının ön uygulaması, 2016-2017 eğitimöğretim yılı ikinci dönemi içinde, Denizli il merkezindeki bir devlet okulunun 7. sınıf öğrencileriyle gerçekleştirilmiştir. Pilot çalışma 9 hafta sürmüştür. Hazırlanan ve uygulanan senaryo metinleri ile çalışma kâğıtlarında aksayan yönler belirlenmiştir. Böylelikle, hazırlanan senaryoların uygun şekilde çalışıp çalışmadığı sınanmıştır. Ayrıca öğrencilerden alınan görüşler doğrultusunda bazı senaryolarda gerekli düzenlemeler ve iyileştirmeler yapılmıştır. Ön uygulamanın ardından, bilimsel araştırma yöntem basamaklarını içeren senaryo çalışma yaprakları son halini almıştır.

\subsubsection{Deney Grubunda Yapılan Uygulamalar}

Deney grubu; 3-4 kişilik, homojen olmayan, sekiz ayrı gruptan oluşmaktadır. Her bir gruba ait oturma planı yapılmış, kendilerine bir başkan, bir yazıcı ve bir sözcü seçmeleri istenmiştir. Deney grubu öğrencileri araştırma süresince fen bilimleri laboratuvarını kullanmıştır.

Uygulama öncesinde, ön testler uygulandıktan sonra, araştırmacı rehberliğinde deney grubu öğrencileri ile probleme dayalı öğrenme yöntemi ve yöntemin uygulanma şekline yönelik bir hazırlık uygulaması yapılmıştır. Yapılan hazırlık uygulamasında araştırma konusu olan ünite haricinde bir problem durumu öğrencilere sunulmuştur. Sunulan problem durumuna yönelik örnek bir senaryonun çalışması öğrenciler ile birlikte gerçekleştirilmiştir. Bu ön hazırlık çalışmasının uygulanma sebebi, öğrencilerin ilk defa PDÖ yöntemi ile karşılaşıyor olmalarıdır. Hazırlık uygulaması sürecinde çalışmaların nasıl yapılacağı ile ilgili gerekli açıklamalar (yöntemin uygulanmas1, grup oluşturma süreci, gruplarda üye seçimi ile görevlerin paylaşımı, öğrenci ve öğretmenin rolleri, uygulama ortamı ve kullanılacak materyallerin seçimi ve temin edilme süreçleri, senaryo çalışma kâğıtlarının nasıl doldurulacağı) yapılmıştır. Gerçekleştirilen ön hazırlık uygulamasında öğrenciler tarafından merak edilen sorular araştırmacı tarafından yanıtlanmıştır. Öğrencilerin, gerçekleştirilen ön PDÖ uygulaması (3 ders saati) ile deneyimleri doğrultusunda tecrübe kazanmaları hedeflenmiştir.

Deney grubu öğrencilerine uygulama öncesinde hazırlanan bir yönerge kâğıdı dağıtılmıştır. Yönerge kâğıdını takip ederek öğrencilerin senaryo çalışma kâğıtlarını uygun şekilde doldurmaları istenmiştir. Senaryo çalışma kâğıltarı gruplarda bulunan öğrenci sayısı kadar çoğaltılarak her bir öğrenciye basılı olarak verilmiştir. Deney grubu öğrencileri, PDÖ yöntemine dayalı dersleri aşağıda verilen basamakları takip ederek gerçekleştirmişlerdir.

- Her bir senaryo 3 oturumda (ortalama 3 ders saati) tamamlanacak şekilde düzenlenmiştir. Senaryolar, oturum başında grup öğrencilerine dağıtılarak öğrencilerin grup halinde beraber çalışmaları sağlanmıştır. Senaryo metinleri, grup öğrencilerinin her biri tarafından okunduktan sonra çalışma kâğıdına ait belli kısımları kendi başlarına, bazılarını ise grupça arkadaşlarıyla birlikte aldıkları ortak kararlarına göre doldurmaları istenmiştir. Senaryo çalışma kâğıtlarında, öğrencilerin senaryo metinlerinde bulunan problemi belirleyebilmelerini sağlayacak bir veya birkaç soru yer almaktadır. Sunulan soru/lar yardımıyla öğrencilerden problemi belirlemeleri, değişkenleri tespit etmeleri ve verilen problemin çözümüne yönelik bir hipotez ortaya koymaları beklenmiştir. Öğrenciler, belirledikleri hipotezi test etmeye yönlendirilerek bilimsel araştırma yöntem basamaklarının kullanılması hedeflenmiştir.

- Öğrencilerde var olan bilginin ortaya çıkarılması, varsa eksik veya ihtiyaç duyulan bilginin tespit edilmesi, ihtiyaç duyulan bilgiyi/leri bulma yolu, çalışma boyunca öğrencinin 
benimseyeceği rolü belirlemek amacıyla oluş̧turulan tabloyu doldurmaları (Ne/ler biliyorum?, $\mathrm{Ne} /$ leri öğrenmeliyim?...) istenmiştir ( $E k$ 2).

- Sonraki aşamada öğrenciler, belirlenen problem cümlesi ile hipotezlerini dikkate alarak grupça var olan problemi çözmek amacıyla gerekli araştırmaları yapmışlardır. Öğrenciler, ihtiyaç duydukları bilgiye ulaşmak amacıyla; ders kitabı, çeşitli yardımcı kaynaklar (popüler bilim kitapları dergiler, kaynak ders kitapları) ve internetten (etkileşimli tahta, laboratuvarda bulunan bilgisayar vb.) yararlanmışlardır. Bunun yanı sıra öğrenciler, laboratuvar ortamı haricinde bilgi kaynağı olarak kullandıkları kendilerine ait basılı kaynakları (kitap, dergi vb.) da laboratuvara getirmeleri yönünde teşvik edilmiştir.

Öğrenciler, grup üyeleri ile birlikte aldıkları ortak karar sonucunda belirlenen bir hipotez üzerinde uzlaşmışlardır. Üzerinde uzlaşılan hipotezi dikkate alarak araştırmalarını genişletmişler, araştırma sonucunda elde edilen bilgi/leri derlemişlerdir. Derlenen bilgiler 1şı̆̆ında, belirlenen problemin çözümüne yönelik olarak uygun deney tasarımını gerçekleştirerek uygulamışlardır. Deney tasarım süreçlerinde, öğrencilerin ihtiyaç duydukları malzemeler, imkânlar doğrultusunda laboratuvardan sağlanmıştır. Laboratuvarda ihtiyaçları olan malzemenin bulunmaması durumunda, kendilerinin bizzat temin etmesi sağlanarak takip eden derste yanlarında getirmeleri yönünde öğrenciler teşvik edilmiştir.

- Öğrenciler, grup arkadaşları ile birlikte deney tasarımını oluşturmuşlardır. Deney sürecinde elde edilen veri/leri uygun şekilde kaydetmeye çalışmış (tablo/grafik vb.) ve elde edilen bulgu/ları yorumlamaya çalışmışlardır. Gerçekleştirilen deney süreci ile elde edilen sonucun, grup üyelerinin ortak karar doğrultusunda uzlaştıkları hipotezi destekleyip desteklemediğini ifade etmişlerdir. Öğrenciler, deney tasarımı ve deneyin gerçekleştirilmesi sürecinde karşılaştıkları aksayan yön/ler ve zorluk/lar ile olası tavsiyelerini belirtmişlerdir. Öğrencilerden, yapılan her bir senaryo çalışması sonunda, hem onların öğrendiklerini pekiştirmelerini sağlamak amacıyla hem de varsa eksik ya da yanlış öğrenmelerin önüne geçmek maksadıyla, senaryo konusuna yönelik gündelik yaşamdan örnekler sunmaları istenmiştir. Ayrıca öğrencilere, senaryo metninde yer alan konuya yönelik, merak edilen farklı sorularının olup olmadığı sorusu yöneltilmiştir. Öğrencilerin senaryo konusu ve problem durumu ile ilgili başka soruları varsa bunları ifade etmeleri istenmiştir.

PDÖ’de; öğrenme sürecine aktif katılan, araştırma sürecini planlayan, bilgiye ulaşma yollarını kullanan, fikrini ortaya koyarak grup üyeleri ile birlikte üzerinde tartışan, ortak karara varan, elde ettiği bilgi/leri grup üyeleri ile paylaşan, elde edilen bilginin doğruluğunu sorgulayan bizzat öğrencidir. Kısacası probleme dayalı öğrenme yönteminde, öğrenci kendi öğrenmesinden sorumludur. PDÖ sürecinde öğretmene düşen görev; öğrencinin gerek duyduğu yerde ona rehberlik etmek yani bir yol gösterici olmaktır. Buradan hareketle; deney grubunun uygulaması boyunca araştırmacı, öğrencilere çeşitli soru/lar yönelterek onların senaryo konusu dışına çıkmalarını engellemiştir. Ayrıca öğrencilerin kazandıkları bilgiyi ve edindikleri tecrübeyi yansıtabilmeleri için onlara gerekli imkânı sağlamak için gayret göstermiştir.

\subsubsection{Kontrol Grubundaki Uygulamalar}

Kontrol grubunda dersler, MEB'in İlköğretim Kurumları Fen Bilimleri Dersi Öğretim Programının (2013) önerdiği şekilde PDÖ süreci olmaksızın işlenmiştir. Kontrol grubu öğrencileri; "Kuvvet ve Enerji" ünitesi boyunca, 2017-2018 eğitim öğretim yılında MEB tarafından okullara dağıtılan ders kitaplarında bulunan etkinlikleri gerçekleştirerek derslerini işlemişlerdir. Ders kitabında yer alan konular işlenirken verilen etkinlikler ve deneyler öğrenciler tarafından gerçekleştirilmiş, değerlendirme soruları ve alıştırmalar çözülmüştür. Kontrol grubu öğrencileri, araştırma süresince fen bilimleri laboratuvarını kullanmışlardır.

\subsection{Verilerin Analizi}

Araştırma esnasında toplanan nicel veriler istatistik programı SPSS 16.00 kullanılarak analiz edilmiştir. Veri analizinde öncelikle BSBT'den elde edilen verilerin normallik analizi 
yapılmıştır. Veri setinin normal dağılıma sahip olup olmadı̆̆ çarpıklık ve basıklık katsayılarının dikkate alınması ve Shapiro-Wilks (S-W) normallik testi uygulanarak incelenmiştir. Tablo 1'de deney ile kontrol grubuna ait BSBT, ön test ve son test puan ortalamalarına ilişkin betimsel istatistik değerleri verilmiştir.

Tablo 1. Deney ve Kontrol Grubu BSBT Testine İlişsin Betimsel İstatistikler

\begin{tabular}{|c|c|c|c|c|c|c|c|c|c|}
\hline Grup & Test & $N$ & Min & $\operatorname{Max}$ & Ort. & S.S & Varyans & Çarpıklık & Basıklık \\
\hline \multirow[t]{4}{*}{ Deney Grubu } & BSB & 30 & 5 & 21 & 15,11 & 3,45 & 11,913 & $-0,919$ & 1,502 \\
\hline & Ön- test & & & & & & & & \\
\hline & BSB & 30 & 11 & 26 & 20,36 & 3,22 & 10,378 & $-0,773$ & 1,510 \\
\hline & Son- test & & & & & & & & \\
\hline \multirow[t]{2}{*}{ Kontrol Grubu } & BSB & 27 & 7 & 20 & 14,66 & 3,35 & 15,92 & 0,152 & 0,281 \\
\hline & $\begin{array}{c}\text { On- test } \\
\text { BSB } \\
\text { Son- test }\end{array}$ & 27 & 8 & 23 & 16,70 & 3,50 & 12,29 & $-0,340$ & 0,079 \\
\hline
\end{tabular}

Tablo 1 incelendiğinde, deney grubu öğrencilerin BSBT puanlarının çarpıklık değerlerinin normal dağılım sınırı $(+1,-1)$ değerleri arasında bulunduğu belirlemiştir (Büyüköztürk, 2006). Ayrıca basıklık ve çarpıklık katsayılarının $-1,5$ ile $+1,5$ değerleri arasında bulunduğu durumda veri setinin normal dağılıma sahip olduğu kabul edilmektedir (George ve Mallery, 2010; Tabachnick ve Fidell, 2013). Ayrica hesaplanan BSBT, kontrol grubuna ait ön test puanlarına ait $\mathrm{S}-\mathrm{W} \mathrm{p}=.30 ;(\mathrm{p}>0.05)$ deney grubuna ait BSBT ön test puanlarına ait $\mathrm{S}-\mathrm{W} \mathrm{p}=$ $.21 ;(\mathrm{p}>0.05)$ kontrol grubu son test $\mathrm{S}-\mathrm{W} \mathrm{p}=.746 ;(\mathrm{p}>0.05)$ deney grubu son test $\mathrm{S}-\mathrm{W} \mathrm{p}=.053$; $(\mathrm{p}>0.05)$ olarak bulunmuştur. Buradan hareketle, veri analizinde parametrik testlere yönelik istatistiksel yöntemlerden yararlanılmıştır. İstatistiksel işlemler 0.05 manidarlık düzeyinde değerlendirilmiştir. Deney ile kontrol gruplarına ait BSBT ön test ve son test puanları bağımsız örneklem t-testi ile incelenmiştir. Hem deney grubu hem de kontrol grubunun kendi içinde gerçekleştirilen ölçüm sonuçları bağımlı örneklem t-testi ile incelenmiştir. Bunun yanı sıra yapılan analizlerde etki büyüklüğü değeri için eta kare (ๆ2) katsayısı hesaplanmıştır. Eta kare katsayısı; bağımsız değişkenin bağımlı değişkende açıkladığı varyans oranını belirtir. Eta kare katsayıs1, 0-1 arasında değer alır. Buna göre; '.01' küçük; '.06' orta ve '.14' geniş etki büyüklüğüne sahip olduğu şeklinde yorumlanır (Büyüköztürk, 2006).

\section{BULGULAR}

Öncelikle deney ile kontrol gruplarında, uygulama öncesi yapılan BSBT ön testinden elde edilen veri analizine yer verilmiştir. Devamında ise deney ve kontrol gruplarının uygulama süreci sonunda BSBT son testinden elde edilen veri analizine yer verilmiştir. Ayrıca hem deney grubu hem de kontrol grubunun ayrı ayrı ön test ve son test sonuçları karşılaştırılmıştır.

Deney ile kontrol grubu öğrencilerine ön test olarak uygulanan BSBT testinden alınan puanlar, parametrik testlerden bağımsız örneklem t-testiyle incelenmiştir. Bağımsız örneklem ttesti sonuçları Tablo 2'de sunulmuştur.

Tablo 2. Deney ve Kontrol Grubu BSBT Ön Test Puanlarının Karşılaştırılmasına İlişkin Bağımsız Örneklem t-testi Analiz Sonuçları

\begin{tabular}{lcccccc}
\hline Ölçüm (BSBT) & $\mathrm{N}$ & $\overline{\mathrm{X}}$ & $\mathrm{ss}$ & $\mathrm{sd}$ & $\mathrm{t}$ & $\mathrm{p}$ \\
\hline Ön test (Deney Grubu) & 30 & 15,13 & 3,45 & 55 & $-0,523$ & 0,603 \\
Ön test (Kontrol Grubu) & 27 & 15,66 & 4,23 & & & \\
\hline$p>.05$ & & & & & &
\end{tabular}

Tablo 2 incelendiğinde; deney ile kontrol grubu öğrencilerine ait BSBT ön test puanları bağımsız örneklem t-testi ile incelendiğinde gruplar arasında istatistiksel olarak .05 manidarlık 
düzeyinde anlamlı bir farklılık olduğu göze çarpmaktadır $\left(\mathrm{t}_{(55)}=-0,523 ; \mathrm{p}>.05\right)$. Deney grubundaki ögrencilerin BSBT ön test puanlarına ait ortalama 15,13 iken; kontrol grubundaki öğrencilere ait BSBT ön test puanlarının ortalaması 15,66'dır. BSBT ön test puanları değerlendirildiğinde deney ile kontrol grubu öğrencilerine ait BSBT ön test puanlarının ortalama değerlerinin birbirlerine yakın olduğu görülmektedir.

Deneysel işlem sonrası yapılan BSBT testi deney ile kontrol grubundaki öğrencilere ait test puanları arasında anlamlı bir farklılı̆gı olup olmadığını belirlemek amacıyla parametrik testlerden bağımsız gruplar t-testi uygulanmıştır. Bağımsız gruplar t-testi sonuçları Tablo 3 'te sunulmuştur.

Tablo 3. Deney ile Kontrol Grubu BSBT Son Test Puanlarının Karşılaştırılmasına İlişkin Bağımsız Örneklem t-testi Analiz Sonuçları

\begin{tabular}{lcccccc}
\hline Ölçüm (BSBT) & N & $\bar{X}$ & Ss & sd & t & p \\
\hline Son test (Deney Grubu) & 30 & 20,36 & 3,22 & 55 & 4,111 & $0,00^{*}$ \\
Son test (Kontrol Grubu) & 27 & 16,70 & 3,50 & & & \\
\hline
\end{tabular}

" $\boldsymbol{p}<.05$ Cohen's d= 1,08 $\eta^{2}=0,23$

Tablo 3'e göre; deney ile kontrol grupları BSBT son test puan ortalamaları arasında istatistiksel olarak 05 manidarlık düzeyinde anlamlı bir farklılık göze çarpmaktadır $\left(\mathrm{t}_{(55)}=\right.$ $4,111 ; \mathrm{p}<.05)$. Deney grubundaki öğrencilerin BSBT son test puanlarına ait ortalama 20,36 iken, kontrol grubundaki öğrencilerin BSBT son test puanlarına ait ortalama 16,70'dir. Buna göre; deney grubundaki öğrencilerin BSBT son test puan ortalamasının kontrol grubundaki öğrencilerin BSBT son test puan ortalamasından daha yüksektir. Etki büyüklüğü 0.00-1.00 arasında değer alır ve önerilen ölçütlere göre şu şekilde yorumlanmıştır. Elde edilen değer; .01 ve altındaysa küçük (düşük), .01-.06 arasındaysa orta, .14 ve daha üzerindeyse büyük (geniş) düzeyde bir etkiye sahip olduğu yorumu yapılır (Büyüköztürk, 2006). Elde edilen Cohen d değeri 1,08' dir. Etki büyüklüğünü belirlemek için hesaplanan $\eta^{2}$ (eta kare) değeri; 0,23 olarak bulunmuştur. Buna göre, BSBT son test puanlarına ait varyansın \%23'ünün uygulanan yönteme bağlı olarak ortaya çıktığı yorumu yapılabilir. Eta kare değeri $\left(\eta^{2}=0,23\right)$ büyük düzeyde bir etkiye sahip olduğunu göstermektedir. Bu bulgular 1şığında; deney grubundaki öğrencilerin BSBT son test puanlarına göre, kontrol grubundaki öğrencilere kıyasla daha başarılı oldukları görülmektedir.

Deneysel işlem öncesi ve sonrasında kontrol grubunda yapılan BSBT testine ait puanlar parametrik testlerden bağımlı örneklem t-testiyle analiz edilmiştir. Tablo 4 'te bağımlı örneklem t-testine ait sonuçlar sunulmuştur.

Tablo 4. Kontrol Grubuna Ait BSBT Ön Test ve Son Test Puan Karşıllaştırmasına İlişkin Bağımlı Örneklem t-testi Analiz Sonuçları

\begin{tabular}{lcccccc}
\hline Ölçüm (BSBT) & N & $\bar{X}$ & Ss & sd & t & p \\
\hline Ön test (Kontrol Grubu) & 27 & 15,66 & 4,23 & 26 & $-0,844$ & 0,407 \\
Son test (Kontrol Grubu) & 27 & 16,70 & 3,50 & & & \\
\hline
\end{tabular}

$p>.05$

Tablo 4'e göre; kontrol grubundaki öğrencilerin BSBT ön test ile son test puan karşılaş̧ırmasına yönelik bağımlı örneklem t-testi analizi sonucunda istatistiksel olarak anlamlı bir farkın olmadığı ortaya çıkmıştır $\left(\mathrm{t}_{(26)}=-0,844 ; \mathrm{p}>.05\right)$. Tabloya göre, kontrol grubundaki öğrencilerin uygulama öncesi BSBT ön test puanlarının ortalaması 15,66 iken, BSBT son test puanlarının ortalaması 16,70 'dir. Kontrol grubuna ait BSBT son test puanları ile ön test puanları kıyaslandığında aralarında az miktarda bir fark olduğu belirlenmiştir. Bu durum; kontrol grubu 
öğrencilerinin takip ettikleri mevcut öğretim yönteminin, öğrencilerin bilimsel süreç becerileri üzerinde yeterli düzeyde bir etkiye sahip olmadığ 1 şeklinde yorumlanabilir.

Deneysel işlem öncesi ve sonrasında deney grubunda yapılan BSBT testine ait puanlar parametrik testlerden bağımlı örneklem t-testiyle analiz edilmiştir. Tablo 5'te bağımlı örneklem t-testine ait sonuçlar sunulmuştur.

Tablo 5. Deney Grubuna Ait BSBT Ön Test ve Son Test Puan Karşılaştırmasına İlişkin Bağımlı Örneklem t-testi Analiz Sonuçları

\begin{tabular}{lcccccc}
\hline Ölçüm (BSBT) & $\mathrm{N}$ & $\overline{\mathrm{X}}$ & $\mathrm{Ss}$ & $\mathrm{sd}$ & $\mathrm{t}$ & $\mathrm{p}$ \\
\hline Ön test (Deney Grubu) & 30 & 15,13 & 3,45 & 29 & $-6,435$ & $0,00^{*}$ \\
Sontest (Deney Grubu) & 30 & 20,36 & 3,22 & & & \\
\hline
\end{tabular}

${ }^{*} p<.05$ Cohen's d $=1,56 \quad \eta^{2}=0,41$

Tablo 5'e göre; deney grubundaki öğrencilerin BSBT ön test ile son test puan karşılaştırmasına yönelik bağımlı örneklem t-testi analizi sonucunda istatistiksel olarak anlamlı bir farkın olduğu ortaya çıkmıştır $\left(\mathrm{t}_{(29)}=-6,435 ; \mathrm{p}<.05\right)$. Tabloya göre; deney grubundaki öğrencilerin uygulama öncesi BSBT ön test puanlarının ortalaması 15,13 iken, uygulama sonrasında BSBT son test puanlarının ortalaması 20,36 olmuştur. Hesaplanan Cohen d değeri 1,56' dir. Etki değeri $\eta^{2}$ (eta kare) değeri 0,41 olarak hesaplanmıştır. Hesaplanan eta kare değerine göre; deney grubu BSBT test puanlarına ait varyansın \% 41' inin uygulanan probleme dayalı öğrenme yöntemine bağlı olarak ortaya çıktığ 1 ifade edilebilir. Eta kare değeri $(\eta 2=0,41)$ büyük düzeyde bir etkiye sahip olduğunu göstermektedir. Bu bulgular 1şığında; Probleme Dayalı Öğrenmenin deney grubunu oluşturan öğrencilerin, bilimsel süreç becerileri üzerinde olumlu katkısı ortaya çıkmıştır. Kısacası; deneysel uygulama sonucunda deney grubunu oluşturan öğrencilerin BSBT test puanları, kontrol grubunu oluşturan öğrencilerin BSBT test puanları ile kıyaslandığında, deney grubu öğrencilerinin kontrol grubu öğrencilerinden daha başarılı oldukları sonucuna ulaşılmıştır.

\section{TARTIŞMA VE SONUÇ}

Ortaokul 7. sınıf Fen Bilimleri dersi müfredatında yer alan "Kuvvet ve Enerji” ünitesinin öğretiminde kullanılan bilimsel araştırma yöntem basamaklarını içeren senaryo çalışma yaprakları ile PDÖ'nün öğrencilerin bilimsel süreç becerileri üzerindeki etkisini incelenmeyi amaçlayan bu çalışmada, elde edilen bulgular incelendiğinde; deney ve kontrol gruplarında deneysel işlem öncesi uygulanan BSBT ön test puanları arasında anlamlı bir farkın olmadığ tespit edilmiştir. Yarı deneysel olarak yürütülen araştırma sonucunda; deneysel işlem sonrasında deney grubundaki öğrencilerin BSBT son testinde kontrol grubundaki öğrencilere kıyasla daha başarılı oldukları belirlenmiştir. Bu durum; bilimsel araştırma yöntem basamaklarını içeren senaryo çalışma yaprakları doğrultusunda uygulanan PDÖ’nün, öğrencilerin bilimsel süreç becerilerini geliştirmede etkili olduğunu göstermektedir.

Yapılan araştırmada; kontrol grubundaki öğrencilerin BSBT ön test ve son test puan ortalamalarının kıyaslanmasına yönelik yapılan bağımlı örneklem t-testi analizi sonucunda, istatistiksel olarak manidar bir farklılık tespit edilmiştir. Elde edilen bu sonuç; kontrol grubu öğrencileri ile yürütülen mevcut öğretim yönteminin, bilimsel süreç becerileri üzerinde etkili olduğunu, buna karşın ortaya çıkan farkın deney grubu öğrencilerinin son test puanları ile kıyaslandığında daha az olduğunu ortaya koymuştur. Ortaya çıkan bu durum; kontrol grubunda takip edilen öğretim yöntemine dayandırılmıştır. Kontrol grubu öğrencileri; mevcut öğretim yöntemi çerçevesinde fen bilimleri derslerini takip etmişlerdir. Bu süreç boyunca fen bilimleri derslerinde MEB tarafindan okullara dağıtılan mevcut ders kitabından yararlanılmıştır. Dolayısıyla; elde edilen bu sonuç; fen bilimleri ders kitabında yer alan etkinliklerin, 
öğrencilerde bilimsel süreç becerilerinin geliştirilmesinde yeterli düzeyde etkiye sahip olmadığ 1 şeklinde ifade edilebilir. Araştırmanın kontrol grubuna dayalı olarak elde edilen bu sonuç ile alan yazında benzerlik gösteren çalışmaların olduğu bilinmektedir (Büyükdokumacı, 2012; Söyleyici, 2018; Şencan, 2013; Tekin, 2019). Örneğin; Tekin, (2019) 7. sınıf öğrencilerinin "Aynalarda Yansıma ve Işığın Soğurulması” adlı konuların öğretimi sürecinde uyguladığı probleme dayalı öğretim yaklaşımının, öğrencilerin akademik başarıları, bilimsel süreç becerileri ve fen öğrenme motivasyonlarına etkisini incelemiştir. 4 hafta süren ve karma modelin uygulandığı araştırmada; PDÖ yaklaşımı ile deney grubu, yapılandırmacı yaklaşım ile kontrol grubu öğrencileri ders işlemişlerdir. Araştırmanın sonucunda, deney ile kontrol grubundaki öğrencilerin arasında bilimsel süreç becerileri, motivasyon ile akademik başarıları açısından manidar bir fark bulunmamıștır. Buna karşın, bilimsel süreç becerileri testi ve fen öğrenmeye yönelik motivasyon ölçeği sonuçları incelendiğinde bilimsel süreç becerileri açısından, deney grubunun ön test ve son test puanları arasında anlamlı bir farkın olduğu ortaya konmuştur. Bununla birlikte; kontrol grubunda, bilimsel süreç becerileri son test ortalama puanlarında artış gözlenmiş olmasına karşın bu artışın anlamlı bir fark yaratmadığ belirlenmiş̧ir. Şencan (2013), araştırmasında; 7. sınıf "Kuvvet ve Hareket" ünitesi kapsamında günlük yaşamdan alınan problemlerin bulunduğu problem çözme etkinliklerini içeren öğretim yönteminin, bilimsel süreç becerileri, akademik başarıları ile bilim okuryazarlığına etkisini incelemiştir. Yarı deneysel olarak yürütülen çalışmada; kontrol grubunda dersler mevcut program doğrultusunda yapılandırmacı yaklaşıma dayalı olarak, deney grubunda ise günlük yaşam problemlerine dayanan öğretim yöntemi ile yürütülmüştür. Araştırmanın sonucunda; deney grubunda uygulanan yöntemin, öğrencilerin bilimsel süreç becerileri ile bilim okuryazarlığının alt boyutlarından biri olan bilimin doğasına ilişkin anlayışlarını geliştirmede, kontrol grubuna kıyasla daha etkili olduğu sonucuna ulaşılmıştır. Akademik başarı açısından değerlendirildiğinde ise; deney grubunda uygulanan problem çözme etkinliklerine dayalı ögretim yönteminin, kontrol grubunda uygulanan yapılandırmacı yaklaşımla benzer bir etkiye sahip olduğu sonucuna ulaşılmıştır.

$\mathrm{Bu}$ araştırmada; deney grubunun deneysel işlem öncesi BSBT ön test puanları ile deneysel işlem sonrası deney grubuna uygulanan BSBT son test puanları arasında manidar bir farklılık ortaya çıkmıştır. Ortaya konan bu bulgunun 1şı̆̆ında; PDÖ'nün deney grubunu oluşturan öğrencilerin bilimsel süreç becerileri üzerinde olumlu bir katkısının olduğu belirlenmiştir. Ayrıca hesaplanan Cohen's d değeri, geniş bir etki düzeyine işaret etmektedir. $\mathrm{Bu}$ durum; deney grubuna ait BSBT test puanları varyansının \% 41'inin yürütülen PDÖ yöntemine bağlı olduğunu göstermektedir. Bu sonucun elde edilmesinde; deney grubunda PDÖ yöntemine dayalı uygulanan bilimsel araştırma yöntem basamaklarını içeren senaryo çalışma yapraklarının etkili olduğu görülmektedir. Ayrıca bilimsel araştırma yöntem basamaklarını içeren senaryo çalışma yaprakları, bilimsel süreç becerilerini geliştirmede olumlu katkıya sahiptir. Alan yazında probleme dayalı öğrenme yaklaşımının kullanıldığı çalışma gruplarında, bilimsel süreç becerilerindeki değişimleri ortaya koyan ve yapılan bu çalışmanın bulguları ile benzerlik gösteren başka çalışmalar da mevcuttur (Aydoğdu, 2012; Büyükdokumacı, 2012; Demirel, 2014; Kartal Taşoğlu, 2009; Oskay, 2007; Pakyürek Karaöz, 2008; Söyleyici, 2018; Şahbaz ve Hamurcu, 2012; Tatar, 2007; Tatar ve Oktay, 2011; Tavukcu, 2006; Temel ve Morgil, 2007). Örneğin; Söyleyici (2018) çalışmasında; ilköğretim 7. sınıf "Işık" ünitesinde uyguladığı PDÖ'nün öğrencilerinin bilimsel süreç becerileri, bilimsel tutumlarına, akademik başarıları ile kavram bilgilerine etkisini araştırmıştır. Araştırmada, ön test ve son test kontrol gruplu yarı deneysel desen kullanılmıştır. 5 hafta süren araştırmada "Işık" ünitesi deney grubunda PDÖ kullanılarak, kontrol grubunda ise mevcut fen programı takip edilerek yürütülmüştür. Araştırma sonucunda; elde edilen veriler doğrultusunda; PDÖ’nün yürütüldüğü deney grubundaki öğrenciler ile mevcut fen müfredatının yürütüldüğü kontrol grubundaki öğrencilere ait bilimsel süreç becerileri, akademik başarı ile kavram bilgileri arasında deney grubu lehine manidar bir fark ortaya çıkmıştır. Ayrıca; deney grubunda yürütülen PDÖ uygulamasının, öğrencilerin bilimsel süreç becerilerini geliştirmedeki olumlu etkisine vurgu 
yapılmıştır. Benzer olarak; Şahbaz ile Hamurcu (2012), 5. Sınıf Fen ve Teknoloji dersinde "Maddenin Tanınması ve Değişimi” ünitesi kapsamında işbirliğine dayalı öğrenme yöntemiyle PDÖ'nün bilimsel süreç becerileri, akademik başarıları ile hatırda tutma düzeyleri üzerine etkisini incelemiştir. Yarı deneysel olarak yürütülen araştırmada yer alan iki deney grubundan birinde fen dersleri; PDÖ ile yürütülürken, deney grubu öğrencileri işbirliğine dayalı olarak fen derslerini işlemişlerdir. Kontrol grubu öğrencileri MEB tarafından tavsiye edilen öğretim yöntemiyle derslerini takip etmişlerdir. Çalışma sonunda; PDÖ ile işbirlikli öğrenmenin mevcut öğretim yöntemine nazaran bilimsel süreç becerilerini ve akademik başarılarını geliştirmekte olumlu katkısının olduğu ortaya konmuştur. Büyükdokumacı (2012) ise; 8. sınıf fen ve teknoloji dersi kapsamında "Maddenin Halleri ve Isı" ünitesi çerçevesinde yürütülen PDÖ yönteminin, öğrencilerin akademik başarılarına, bilimsel süreç becerilerine ve problem çözme tutumlarına etkisini araştırmıştır. 8 hafta süren ve yarı deneysel desene göre yürütülen çalışmada dersler; kontrol grubu öğrencileri sorgulamaya dayalı öğrenme yöntemiyle, deney grubu öğrencileriyse PDÖ ile ders ișlemişlerdir. Çalıșma sonucunda; öğrencilerin akademik başarıları ile bilimsel süreç becerileri bağlamında, deney grubu lehine manidar bir fark tespit edilmiştir. Kontrol grubu öğrencileri ile yürütülen sorgulamaya dayalı mevcut öğretim programının, bilimsel süreç becerileri üzerinde yeterli düzeyde geliştirici etkiye sahip olmadığı belirtilmiştir. Bununla birlikte problem çözme becerileri bağlamında, deney grubu öğrencileri ile kontrol grubu öğrencileri arasında manidar bir fark tespit edilmemiştir. Bunun yanı sıra, deney grubunda PDÖ uygulaması süresince kullanılan senaryo çalışma kâğıtlarının değerlendirilmesi sonucu; öğrencilerinin bilimsel süreç becerileri değerlendirme ölçeğinden aldıkları puanlar ile bilimsel süreç becerileri arasında anlamlı bir ilişki olduğu belirlenmiştir.

Bununla birlikte, yapılan bu çalışmadan elde edilen bulgular ile alan yazında mevcut olan bazı çalışmaların bulguları örtüşmemektedir (Çelik, 2013; Elbistanlı, 2012; Serin, 2009; Şahbaz, 2012; Urtekin, 2012; Yıldız, 2010). Bunlardan biri Serin (2009)'in 7. sınıf "Basınç" ünitesinde probleme dayalı öğrenme yöntemine (PDÖ) dayanan bireysel ve grup çalışmalarının öğrencilerin ders başarılarına, derse yönelik tutumuna ve bilimsel süreç becerilerine etkisini araştırdığı çalışmadır. Yarı deneysel olarak yürütülen bu çalışmada, çalışma grubunu oluşturan sınıflardan dördü kontrol, diğer dördü deney grupları olarak seçilmiştir. Deney gruplarında fen bilimleri dersleri; probleme dayalı öğrenme yöntemiyle, kontrol gruplarında geleneksel yönteme bağlı kalınarak yürütülmüştür. Deney grupları; kendi aralarında, probleme dayalı öğrenmenin uygulandığı 'bireysel' ve 'grup' çalışmalarına dayalı olarak iki farklı deney grubu üzerinden yürütülmüştür. Araştırmanın neticesinde; gruplar birbirleri ile kıyaslandığında, fen dersine yönelik tutumları, bilimsel süreç becerileri ile akademik başarıları bağlamında manidar bir fark ortaya çıkmadığı ifade edilmiştir. Bu sonuca neden olan etmenlerden biri; uygulamanın yapıldığı öğretim dönemi diğeri ise uygulanan testlerin uygulama zamanı olarak belirtilmiştir. Araştırmacı ayrıca öğrencilerin daha çok sağlık alanı ile ilgili konulara ilgi duyduklarını belirtmektedir. $\mathrm{Bu}$ nedenle öğrencilerin ilgi alanları son test puanları üzerinde etkili olmuş olabilir. Bunun yanı sıra araştırmacı; uygulamanın son testlerinin dönem sonuna yakın, havanın giderek 1sındığı bir zamanda yapıldığını ve bu durumun testlerdeki puan değerleri üzerinde etkili olduğu yorumunu yapmıştır. Yıldız (2010), çalışmasında; 6. sınıf "Maddenin Tanecikli Yapısı" ünitesinde PDÖ senaryolarına dayalı deney uygulamalarının öğrencilerin akademik başarılarına, tutumları ile bilimsel süreç becerileri üzerine etkisini araştırmıştır. Yarı deneysel olarak yürütülen çalışmanın deney grubu öğrencileri, PDÖ senaryolarına uygun olarak hazırlanan ve PDÖ senaryolarını çözüme kavuşturacak deney uygulamalarını kapsayan etkinlikler üzerinde çalışmışlardır. Kontrol grubu öğrencileriyse; yapılandırmacılığa dayanan, var olan fen müfredatını takip etmişlerdir. Araştırmada; deney grubu öğrencilerinin akademik başarılarının kontrol grubu öğrencilerine nazaran daha yüksek olduğu ortaya çıkmıştır. Buna karşın, deney grubu ve kontrol grubunun fen derslerine yönelik tutumlar ile bilimsel süreç becerileri arasında hem gruplar arasında hem de her bir grup içinde manidar bir fark bulunamamıştır. 
$\mathrm{Bu}$ araştırmada; deney grubunun BSBT elde edilen son test puanlarının ve kontrol grubu BSBT son test puanlarından yüksek olduğu göze çarpmıștır. Yapılan bağımsız gruplar t testi sonucunda deney ve kontrol gruplarına ait BSBT son testleri birbiriyle kıyaslandığında deney grubundaki öğrenciler lehine manidar bir fark tespit edilmiştir. Hesaplanan Cohen d değeri geniş bir etki düzeyini işaret etmektedir. Ayrıca hesaplanan $\eta^{2}$ (eta kare) değeri; BSBT son test puan varyansının \%23'ünün uygulanan yönteme bağlı olarak ortaya çıktığını belirtmektedir. Sonuç olarak; deneysel işlem sonucunda, deney grubundaki öğrencilerin BSBT'nde, kontrol grubundaki öğrencilere kıyasla daha başarılı oldukları belirlenmiştir. Elde edilen bu bulgu doğrultusunda; PDÖ'nün deney grubundaki öğrencilerin bilimsel süreç becerilerini geliştirmekte olumlu bir katkısı olduğu ifade edilebilir. Elde edilen bu sonuç ile paralellik gösteren Sağdıç, Bakırcı ve Boynukara (2019) çalışmaları verilebilir. Sağdıç, Bakırcı, Boynukara (2019) araştırmalarında; 7. sınıf "Kuvvet ve Enerji" ünitesi kapsamında rehberli sorgulama modelinden yararlanılan fen öğretiminin, öğrencilerin bilimsel süreç becerileri üzerine etkisini incelemişlerdir. Yarı deneysel olarak 4 hafta yürütülen çalışmada; deney grubu dersleri rehberli öğretim modeli ile, kontrol grubu dersleri ise 5E öğretim modeli ile işlenmiştir. Araştırmanın sonucunda; rehberli sorgulama öğretim modeli ile yürütülen derslerin, mevcut öğretim programına dayalı $5 \mathrm{E}$ öğretim modeline kıyasla öğrencilerin bilimsel süreç becerilerini geliştirmede daha etkili olduğu ortaya çıkmıştır. Putri (2017), çalışmasında; bilimsel araştırmaya dayalı öğrenme modelini kullanan fizik öğrencilerinin edindiği bilimsel süreç becerilerinin, geleneksel öğrenme modelini kullanan öğrencilerin kazandığı bilimsel süreç becerilerinden daha yüksek düzeyde olduğu sonucuna ulaşmıştır. 68 öğrenci ile gerçekleştirdiği çalışmasında; ayrıca, bilimsel araştırma öğrenme modeli ile kullanılan bilimsel argümantasyon arasında olumlu bir ilişki olduğunu belirlemiştir. Bir başka çalışmada; Demirel (2014), 10. sınıf kimya dersi "Karışımlar" konusu kapsamında PDÖ ve "Argümantasyona Dayalı Öğrenme" yöntemleri uygulanarak, uygulanan yönteminin akademik başarıları, bilimsel süreç becerileri ile bilimsel muhakeme yetenekleri üzerindeki etkisini incelemiştir. Elde edilen bulgular; probleme dayalı öğrenme yönteminin yanı sıra argümantasyona dayalı öğrenme yönteminin de akademik başarı ile bilimsel süreç becerilerini geliştirmekte, var olan öğretim programına nazaran daha olumlu etkileri olduğunu ortaya çıkarmıştır. Bununla birlikte; bilimsel süreç becerileri açısından değerlendirildiğinde argümantasyona dayalı öğrenme yönteminin PDÖ'ye nazaran daha etkili olduğu sonucuna ulaşılmıştır. Pakyürek Karaöz (2008), İlköğretim 6. sınıf Fen ve Teknoloji "Kuvvet ve Hareket" ünitesinin öğretiminde uygulanan probleme dayalı öğrenmenin; bilimsel süreç becerileri, akademik başarıları ile tutumlarına etkisini incelemiştir. Yarı deneysel olarak yürütülen çalışmada; deney grubu öğrencileri ilgili üniteyi PDÖ’ye dayalı olarak işlerken, kontrol grubu öğrencileri adı geçen üniteyi var olan öğretim programı doğrultusunda PDÖ olmaksızın işlenmiştir. 6 hafta süren çalışma sonucunda; akademik başarıları ile bilimsel süreç becerilerinde deney grubu lehine manidar bir fark tespit edilmiştir. Buna karşın; deneysel işlem sonucunda, deney grubundaki öğrencilerin tutum puanı ile kontrol grubundaki öğrencilerin tutum puanı kıyaslandığında manidar bir fark bulunamamıştır. Bununla birlikte; Urtekin (2012) ise; 7. sınıf öğrencilerinin, "Kuvvet ve Hareket" ünitesi kapsamında işe koştukları bilimsel süreç becerilerini etkin kullanabilme durumları ile bu süreci etkileyebileceği düşünülen değişkenleri ortaya çıkarmak amacıyla bir çalışma yapmıştır. Araştırma sonucunda; çalışma boyunca öğrencilere ait ders kitapları ve ders defterleri incelenmiştir. Ayrıca öğrencilerin ders sınıf içi performansları gözlemlenmiştir. Elde edilen bulgular; öğrencilerin bilimsel süreç becerilerini etkin kullanma durumları ile uyguladıkları öğrenme stratejileri arasında olumlu bir ilişkinin olduğunu ortaya çıkarmıştır. Bununla birlikte; alınan öğrenci görüşleri neticesinde, işe koşulan bilimsel süreç becerileri ile takip edilen öğrenme stratejisi arasında çok zayıf bir ilişkinin varlığ 1 açığa çıkarılmıştır. Bunun yanı sıra, öğrencilerin işe koştukları bilimsel süreç becerileri ile cinsiyetleri ile ebeveynlerinin öğrenim durumları arasında manidar bir ilişkinin olmadığı ortaya çıkmıştır.

Hung, Jonassen ile Liu (2008) probleme dayalı öğrenmenin, eğitim tarihindeki en yenilikçi öğretim yöntemi olduğunu ileri sürmüşlerdir. Fen bilimleri dersleri; akıl yürütme, 
sorgulama gibi sürece dayalı olan becerilerin öğrencilere kazandırılmasında ve bu becerilerin etkili bir biçimde kullanılmasında büyük bir öneme sahiptir. Bilimsel araștırma süreç basamakları ile probleme dayalı öğrenme basamakları arasında benzerlikler bulunmaktadır. Probleme dayalı öğrenme, öğrencinin bilimsel düşünme becerilerini aktif olarak kullanmasında etkilidir (Gallagger vd., 1995). PDÖ ile yürütülen fen öğretimi, bilimsel düşünme süreçleriyle bilimsel süreç becerilerinin öğrenciye kazandırılmasında etkilidir. Bilimsel süreç becerileri ile öğrenciler, bir bilim insanı misali çeşitli metod ve işlem basamaklarını takip ederek bir ilkeye, yasaya ya da bir teoriye nasıl ulaşacaklarını öğrenirler (Can, Gencer, Yıldırım ve Bahtiyar, 2016; s.8). Buradan hareketle; sonuç olarak, 7. sınıflar "Kuvvet ve Enerji" ünitesinin öğretimi sırasında yürütülen yarı deneysel bu araştırma sonucunda, PDÖ'ye dayalı bilimsel araștırma basamaklarını içeren senaryo çalışma yapraklarının, öğrencilere, uygulama sürecince bilimsel süreç becerilerinin kazandırılmasında ve bu becerilerin geliştirilmesinde olumlu katkısı olduğu aşikârdır.

Bunun yanı sıra PDÖ yöntemi ile elde edilen kazanımlar ile 21. yüzyıl yaşam becerileri ile revize edilen Ortaokul Fen Bilimleri Öğretim Programı (MEB, 2018) göz önüne alındığında, birçok ortak noktalarının olduğu görülmektedir. İşbirlikli çalışma, etkili iletişim becerileri, yaşam boyu öğrenme bu ortak noktalardan yalnızca birkaç tanesidir. Bu bakış açısı doğrultusunda; probleme dayalı öğrenme yönteminin kullanıldığı dersler, yalnızca adı geçen becerilerin geliştirilmesini sağlamayacak uzun vadede bireylerin esnek düşünme becerilerini kazanmalarında, onların etkili karar alıcılar olabilmelerinde de fayda sağlayacaktır. Ayrıca probleme dayalı öğrenme yöntemi, bireylerin özgüven kazanmaları ve geliştirmeleri, empati kurma becerileri, sosyal iletișim becerileri üzerinde olumlu katkılar sağlayarak onlara destek olmaktadır. Aynı zamanda probleme dayalı öğrenme; fen bilimleri öğretim programının temel amacı olan fen okuryazarı bir birey olabilmelerinde etkilidir. Bunun yanı sira probleme dayalı öğrenme; bireylere araştırma ve sorgulama becerilerini kazandırmanın yanı sıra bilimsel süreç becerilerini etkin kullanma becerilerini desteklemesi dolayisıyla da bir o kadar önemlidir.

Sonuç olarak; tüm ülkeler, bilim okuryazarı birey yetiştirmenin öneminin farkındadır. $\mathrm{Bu}$ amaç doğrultusunda eğitim alanında birçok reform yapılmaktadır. Bu sebeple eğitimde, etkili yöntem ve yaklaşımları kullanmak önemlidir. Gelecek nesillerimiz olan yetiştirmekte olduğumuz öğrencilerin, bilimsel süreç becerilerinin geliştirilmesi bir ülkenin şüphesiz ki geleceğine yaptığı ve yapabileceği en büyük yatırımdır.

\section{ÖNERILER}

Fen eğitiminin temel hedefleri arasında bilimsel süreç becerilerinin kazandırılması ve gelişiminin yer aldığı düşünüldüğünde, yürütülen bu çalışmanın bulguları doğrultusunda, ortaokul 7. sınıf öğrencilerine bilimsel süreç becerilerini kazandırmak ve bu becerilerin gelişimini sağlamak amacıyla bilimsel araştırma yöntem basamaklarını içeren senaryo çalışma yapraklarıyla yürütülen PDÖ'nün kullanılması önerilmektedir. Bunun yanı sıra, öğrencilere bilimsel süreç becerilerinin kazandırılması, geliştirilmesi ve desteklenmesi amacıyla PDÖ yönteminin kullanıldığı öğrenme ortamları öğrencilere sunulmalıdır. Bu amaçla farklı sınıf düzeylerine ve öğrenme alanlarına yönelik bilimsel araştırma yöntem basamaklarını içeren çeşitli senaryo çalışma yapraklarının hazırlanarak uygulanması yerinde olacaktır. Elde edilen araştırma sonuçları doğrultusunda, araştırmacılara, öğretmenlere ve program geliştiricilere yönelik öneriler sunulmuştur;

- Mevcut fen bilimleri ders kitaplarına ya da ileride hazırlanacak olanlara öğrenci yaşı, sınıfı ve öğrenme alanı göz önünde bulundurularak bilimsel araştırma yöntem basamaklarını içeren çeşitli senaryo çalışma yaprakları hazırlanarak ilave edilebilir. Bu sayede öğrencilerin gelişim dönemleri dikkate alınarak, gelişim dönemlerine uygun bilimsel süreç becerileri edinmeleri ve bu becerileri güçlendirmeleri sağlanabilir. Farklı sınıf düzeylerine yönelik olarak 
hazırlanacak olan bilimsel araştırma yöntem basamaklarını içeren senaryo çalışma yapraklarının uygulanabilirliği ile etkililiği ayrıca araştırılabilir.

- Yürütülen bu araştırma esnasında uygulanan bilimsel araştırma yöntem basamaklarını içeren senaryo çalışma yaprakları aracılığı ile bilimsel süreç becerine ait alt boyutlarda (problem belirleme, hipotez kurma, değişken/leri belirleme, veri kaydetme, sonuca varma) meydana gelen değişimleri derinlemesine incelemek amacıyla ilave ve farklı analiz yöntemleri kullanılabilir.

\section{KAYNAKÇA}

Açıkgöz, K. U. (2003). Aktif öğrenme (5. Bask1). İzmir: Kanyılmaz Matbaası

Aka İnce, E. (2012). Asitler ve bazlar konusunun öğretiminde kullantlan probleme dayalı ögrenme yönteminin farkl değiş̧kenler üzerine etkisi ve yönteme iliş̧kin öğrenci görüşleri. (Yayımlanmamış Doktora Tezi). Gazi Üniversitesi Eğitim Bilimleri Enstitüsü. Ankara.

Akınoğlu, O., Özkardeş. ve Tandoğan, R. (2007). The effects of problem-based active learning in science education on students' academic achievement, attitude and concept learning. Eurasia Journal of Mathematics, Science \& Technology Education, 3(1), 71-81.

Aktı Aslan, S. (2019). Probleme dayalı ögrenme yaklaşımına göre tasarlanan sanal öğrenme ortamlarının ögrencilerin başarı, problem çözme becerisi ve motivasyonlarına etkisi. (Yayımlanmamış Doktora Tezi). İnönü Üniversitesi. Malatya.

Alacapinar, F. G. ve Ok, M. (2020). Meta-analysis covering studies on problem-based learning. Research on Education and Psychology (REP), 4 (Special Issue), 53-73.

Ananiadou, K. ve Claro, M. (2009). 21st century skills and competences for new millennium learners in oecd countries. OECD Education Working Papers, No. 41. Paris: OECD Publishing. Erişim:http://dx.doi.org/10.1787/218525261154

Arslan, A. G. ve Tertemiz, N. (2004). İlköğretimde bilimsel süreç becerilerinin geliştirilmesi. Türk Eğitim Bilimleri Dergisi, 2(4), 479-492.

Arslan Turan, B. (2014). Probleme dayall ögrenmenin başartya, öz-düzenleyici öğrenme becerilerine ve akademik özgüvene etkisi. (Yayımlanmış Doktora Tezi). Hacettepe Üniversitesi Eğitim Bilimleri Ensitüsü. Ankara.

Ayaz, M. F. ve Ayaz. N. (2015). Probleme dayalı öğrenme yaklaşımı ile ilgili Türkiye'de yapılmış tezlerin incelenmesi. The Journal of Academic Social Science Studies International Journal of Social Science, 38, 407- 427.

Ayaz, N. (2015). Probleme dayalı öğrenme yaklaşımının öğrencilerin fen bilimleri derslerindeki akademik başarılarına ve tutumlarına etkisi: bir metaanaliz çalışması.(Yayımlanmamış Yüksek Lisans Tezi). Fırat Üniversitesi Eğitim Bilimleri Enstitüsü. Elazığ.

Aydoğdu, C. (2012). Elektroliz ve pil konularının öğretiminde probleme dayalı öğrenme yaklaşımının etkisi. Hacettepe Üniversitesi Eğitim Fakültesi Dergisi, 42, 48-59.

Aydoğdu, B. ve Ergin, Ö. (2012). Fen ve teknoloji dersi "kuvvet ve hareket" ünitesine yönelik bilimsel süreç becerileri ölçeğinin geliştirilmesi, 3(1), 49-62.

Aydoğdu, B., Tatar, N., Yıldız, E. ve Buldur, S. (2012). İlköğretim öğrencilerine yönelik bilimsel süreç becerileri ölçeğinin geliştirilmesi. Kuramsal Eğitimbilim Dergisi, 5(3), 292-311. Erişim: http://dergipark.gov.tr/akukeg/issue/29346/314037

Aydoğdu, B., Buldur, S. ve Kartal, S. (2013). The effect of open-ended science experiments based on scenarios on the science process skills of the pre-service teachers. ProcediaSocial and Behavioral Sciences, 93, 1162-1168. 
Aysu, G. (2019). Probleme dayalı ögrenme tabanl STEM uygulamalarının öğrencilerin akademik başarılarına ve öğrendikleri bilgilerin kalıcılığına etkisinin incelenmesi. (Yayımlanmamış Yüksek Lisans Tezi). Niğde Ömer Halisdemir Üniversitesi. Niğde.

Barrows, H. S. ve Tamblyn, R. M. (1980). Problem-based learning: An approach to medical education. New York: Springer

Boud, D. (Ed.). (1985). Problem-based learning in education for the professions. Sydney, Australia: HERDSA.

Boud, D. ve Feletti, G. (1991). The challenge of PBL. London: Kogan Page Ltd. 13-20.

Büyükdokumac1, H. (2012). Illkögretim 8. sinlf fen ve teknoloji dersinde probleme dayalı ögrenmenin (PDÖ) ögrenme ürünlerine etkisi. (Yayımlanmamış Yüksek Lisans Tezi). Pamukkale Üniversitesi/ Fen Bilimleri Enstitüsü. Denizli.

Büyüköztürk, Ş., Kılıç Çakmak, E., Akgün, Ö. E., Karadeniz, S. ve Demirel, F. (2012). Bilimsel araştırma yöntemleri (18. Baskı). Ankara: PegemA Yayıncılık.

Can, B., Savran Gencer, A., Yıldırım, C. ve Bahtiyar, A. (2016). Fen ögretiminde probleme dayalı ögrenme (5.,6.,7. ve 8. sinıf kazanımlarına yönelik senaryo etkinlikleri). Ankara: PegemA Yayıncilik.

Can, B. ve Şahin Pekmez, E. (2010). Bilimin doğası etkinliklerinin ilköğretim yedinci sınıf öğrencilerinin bilimsel süreç becerilerinin geliştirilmesindeki etkisi, Pamukkale Üniversitesi Eğitim Fakültesi Dergisi, 27, 113-123.

Çelik, E., Eroğlu, B. ve Selvi, M. (2012). Fen eğitiminde probleme dayalı öğrenme yaklaşımının öğrencilerin akademik başarısı ile fen ve teknoloji dersine yönelik tutumlarına etkisi. Kastamonu Eğitim Dergisi, 20(1), 187-202.

Çelik, P. (2013). Probleme dayalı ögrrenmenin öğretmen adaylarının fizik başarısl, öğrenme yaklaşımları ve bilimsel süreç becerileri üzerindeki etkisi.(Yayınlanmamış Doktora Tezi). Dokuz Eylül Üniversitesi/ Eğitim Bilimleri Enstitüsü. İzmir.

Çepni, S., Ayas, A., Johnson, D. ve Turgut, M. F. (1997). Fizik ögretimi. Ankara: YÖK/Dünya Bankası Milli Eğitimi Geliştirme Projesi Hizmet Öncesi Öğretmen Eğitimi Yayınları.

Çepni, S. (2014). Araştırma ve proje çalışmalarına giriş (7. Bask1). Trabzon: Celepler Matbaacilık.

Çınar, D. ve İlik, A. (2013). İlköğretim fen eğitiminde probleme dayalı öğrenme yaklaşımının üst düzey düşünme becerilerine etkisi. Eğitim Bilimleri Araştırma Dergisi,3(2), 21-34.

Dadlı G. (2017). Insan ve çevre ilişkileri ünitesinde otantik probleme dayalı öğrenme etkinliklerinin 7. sinıf ögrencilerinde yansitıcı düşünme becerisi, akademik başarı, çevre tutum ve farkındalıkları üzerine etkisi. (Yayımlanmamış Yüksek Lisans Tezi). Kahramanmaraş Sütçü İmam Üniversitesi/ Eğitim Bilimleri Enstitüsü. Kahramanmaraş.

Dağyar, M. (2014). Probleme dayalı ögrenmenin akademik başarıya etkisi: bir metaanaliz çalışması. (Yayımlanmamış Doktora Tezi). Hacettepe Üniversitesi/ Eğitim Bilimleri Enstitüsü, Ankara.

Demirel, M. ve Arslan Turan, B. (2010). Probleme dayalı öğrenmenin başarıya, tutuma, bilişötesi farkındalık ve güdü düzeyine etkisi. Hacettepe Üniversitesi Eğitim Fakültesi Dergisi, 38, 55-66.

Dewey, J. (1938). Education and experience. Collier Macmillan, New York.

Dewey, J. (1916). Democracy and education. Teddington: Echo Library. 
Divarcı, Ö. F. (2016). Multimedya destekli probleme dayalı öğrenme yaklaşımının 8. sinıf ögrencilerinde akademik başarıya, tutuma ve kalıcıliğa etkisi: basınç konusu. (Yayımlanmamış Yüksek Lisans Tezi). Amasya üniversitesi Fen Bilimleri Enstitüsü. Amasya.

Dönmez Usta, N. ve Kasap, G. (2013). 2000-2012 Y1lları arasında Türkiye'de "kuvvet ve hareket" konusuna yönelik yapılan çalışmalar. Bayburt Üniversitesi Eğitim Fakültesi Dergisi, 8 (2), 76-91.

Duch, B. J., Groh, S. E. ve Allen, D. E. (2001). Why problem-based learning? A case study of institutional change in undergraduate education. The power of problem-based learning. Eds: Duch, B. J., Groh, S. E. And Allen, D. E., Sterling, Virginia, 3-11.

Dursun, C. (2015). Probleme dayalı ögrenme yönteminin ögrencilerin çevre tutumlarına ve farkındalıklarına etkisi (7. Sinıf 'İnsan ve Çevre' ünitesi örneği). (Yayınlanmamış Yüksek Lisans Tezi). Pamukkale Üniversitesi /Eğitim Bilimleri Enstitüsü. Denizli.

Ergin, Ö., Şahin Pekmez, E. ve Öngel Erdal, S. (2005). Kuramdan uygulamaya deney yoluyla fen ögretimi, Dinazor Kitabevi, Birinci Baskı, Kanyılmaz Matbaası, İzmir.

Ekiz, D. (2009). Bilimsel araştırma yöntemleri. Ankara: Anı.

Framework for 21st century learning. http://www.p21.org/abouts/p21framework/262. $(10,12,2017)$.

Gallagher, S. A., Stepien, W. J., Sher, B. T. ve Workman, D. (1995). Implementing problembased learning in science classrooms. School Science and mathematics, 95(3), 136-146.

George, D. ve Mallery, P. (2010). SPSS for windows a step by step: A simple guide and reference.

Gijbels, D., Dochy, F., Van den Bossche, P. ve Segers, M. (2005). Effects of problem-based learning: A meta-analysis from the angle of assessment. Review of Educational Research, 75(1), 27-61.

Glasser, W. (1993). The quality school teacher. New York: Harper Perennial Publisher.

Goodnough K. (2011) Examining the role of students and teachers in problem-based learning. Taking action in science classrooms through collaborative action research. Sense Publishers, 79-90. https://doi.org/10.1007/978-94-6091-583-3_9.

Gray, A. (2016). The 10 skills you need to thrive in the fourth industrial revolution. Paper presented at the World Economic Forum. Obtenida el.

Güzel, Z. (2018). Fen bilimleri ögretiminde öz ve akran değerlendirme uygulamalarının yer aldığ probleme dayalı öğrenme yaklaşımının ögrencilerin başarı ve tutumlarına etkisi. Yüksek Lisans Tezi). Necmettin Erbakan Üniversitesi. Konya.

Harari, Y. N. (2018). 21.yüzyıl için 21 ders (Çeviri: S. Siral). İstanbul: Kolektif Kitap.

Hun, F. (2017). Probleme dayalı öğrenme yöntemi ile geliştirilmiş 5e ögretim modelinin 7. sinıf ögrencilerinin akademik başarl ve tutumlarına yönelik etkisi.(Yayımlanmamış Yüksek Lisans Tezi). Giresun Üniversitesi. Giresun.

Hung, W. (2006). The 3C3R model: A conceptual framework for designing problems in PBL. The Interdisciplinary Journal of Problem-Based Learning, 1(1), 55-57.

Hung, W., Jonassen, D. H. ve Liu, R. (2008). Problem-based learning. In J. M. Spector, J. G. van Merriënboer, M. D., Merrill, \& M. Driscoll (Eds.), Handbook of research on educational communications and technology (3rd ed., pp. 485-506). Mahwah, NJ: Lawrence Erlbaum Associates. 
Hung, W., Jonassen, D. H. ve Liu, R. (2012). Encyclopedia of the sciences of learning. (N. M. Seel, Ed.) Encyclopedia of the Sciences of Learning. Boston, MA: Springer US. doi:10.1007/978-1-4419-1428-6

Hmelo-Silver, Cindy E. (2004). Problem-based learning: What and how do students learn?. Educational Psychology Review, 16(3), 235-266.

İnce Aka, E. (2012). Asitler ve bazlar konusunun öğretiminde kullantlan probleme dayalı ögrenme yönteminin farkl değişkenler üzerine etkisi ve yönteme ilişkin ögrenci görüşleri. (Yayımlanmamış Doktora Tezi). Gazi Üniversitesi/Eğitim Bilimleri Enstitüsü. Ankara.

İnel, D. ve Balım, A. G. (2010). Fen ve teknoloji öğretiminde probleme dayalı öğrenme yöntemi kullanımına ilişkin öğrenci görüşleri. Batı Anadolu Eğitim Bilimleri Dergisi (BAED), 1(1), 1- 13 .

İnel, D. (2012). Kavram karikatürleri destekli probleme dayalı öğrenme yönteminin ögrencilerin problem çözme beceri algılarına, fen öğrenmeye yönelik motivasyonlarına ve kavramsal anlama düzeylerine etkisi. (Yayımlanmamış Doktora Tezi). Dokuz Eylül Üniversitesi/ Eğitim Bilimleri Enstitüsü. İzmir.

İnel, D. (2009). Fen ve teknoloji dersinde probleme dayalı öğrenme yöntemi kullanımının ögrencilerin kavramları yapılandırma düzeyleri, akademik başarıları ve sorgulayıcı ögrrenme becerileri algıları üzerindeki etkileri. (Yüksek Lisans Tezi). Dokuz Eylül Üniversitesi/ Eğitim Bilimleri Enstitüsü. İzmir.

İpek, Y. (2010). Fen ve teknoloji dersinde bilimsel süreç becerilerinin gelişim düzeylerinin belirlenmesi. (Yayınlanmamış Yüksek Lisans Tezi). Yüzüncü Yıll Üniversitesi/ Fen Bilimler Enstitüsü. Van.

Kaptan, F. ve Korkmaz, H. (2001). Fen eğitiminde probleme dayalı öğrenme yaklaşımı. Hacettepe Üniversitesi Ĕ̈itim Fakültesi Dergisi, 20, 185-192.

Karaöz, M. P. (2008). İlkögretim fen ve teknoloji dersi "kuvvet ve hareket” ünitesinin probleme dayalı öğrenme yaklaşımıyla öğretiminin ögrencilerin bilimsel süreç becerileri, başarıları ve tutumları üzerine etkisi. (Yayınlanmamış Yüksek Lisans Tezi).Muğla Üniversitesi/ Fen Bilimleri Enstitüsü. Muğla.

Kartal Taşoğlu, A. (2009). Fizik eğitiminde probleme dayalı ögrrenmenin öğrencilerin başarılarına, bilimsel süreç becerilerine ve problem çözme tutumlarına etkisi. (Yayımlanmamış Yüksek Lisans Tezi). Dokuz Eylül Üniversitesi/ Eğitim Bilimleri Enstitüsü. İzmir.

Keleş, M. (2105). Fen ve teknoloji dersinin işlenişinde probleme dayalı öğrenme yönteminin ögrenci başarılarına ve ögrendiklerini hatırlama düzeylerine etkisi. (Yayımlanmış Yüksek Lisans Tezi). Necmettin Erbakan Üniversitesi. Konya.

K1lınç, A. (2007). Probleme dayalı öğrenme. Kastamonu Eğitim Dergisi, 15(2), 561-578.

Korucu, E. N. (2007). Probleme dayalı ögretim ve işbirlikli öğrenme yöntemlerinin ilkögretim ögrencilerinin başarıları üzerine etkileri. (Yayınlanmamış Yüksek Lisans Tezi). Selçuk Üniversitesi/ Fen Bilimleri Enstitüsü. Konya.

Köseoğlu, F. ve Tümay, H. (2013). Bilim eğitiminde yapılandırıcı paradigma, Ankara: Pegem Akademi.

Kuo, F. R., Hwang, G. J. ve Lee, C. C. (2012). A hybrid approach to promoting students' webbased problem-solving competence and learning attitude. Computers and Education, 58(1), 351-364 
Lee, H. ve Bae, S. (2008). Issues in implementing a structured problem- based learning strategy in a volcano unit: a case study. International Journal of Science and Mathematics, 6(4), 655-676.

Liang, J. C. (2002). Exploring scientific creativity of eleventh grade students in Taiwan. (Yüksek Lisans Tezi). The University of Texas, Austin.

MEB (2006). İlköğretim fen ve teknoloji dersi ögretim programı ve kılavuzu (6,7 ve 8. Sinıflar). Millî Eğitim Bakanlığı Talim ve Terbiye Kurulu Başkanlığı, Ankara.

MEB (2013). Illkögretim kurumları (ilkokullar ve ortaokullar) fen bilimleri dersi (3,4,5,6,7ve 8 . sinıflar) öğretim programı. Millî Eğitim Bakanlığı Talim ve Terbiye Kurulu Başkanlığı, Ankara.

MEB (2017). Fen bilimleri dersi taslak ögretim programı (3, 4, 5, 6, 7 ve 8. Sinıflar). Temel Eğitim Genel Müdürlüğü, Ankara.

MEB (2018). Fen bilimleri dersi öğretim programı (İlkokul ve ortaokul 3, 4, 5, 6, 7 ve 8. sınıflar). Millî Eğitim Bakanlığı Talim ve Terbiye Kurulu Başkanlığı, Ankara.

Moralar, A. (2012). Fen eğitiminde probleme dayalı ögrenme yaklaşımının akademik başarı, tutum ve motivasyona etkisi. (Yayımlanmamış Yüksek Lisans Tezi). Trakya Üniversitesi/ Fen Bilimleri Enstitüsü. Edirne.

National Research Council (NRC) (1996). National science education standards. Erişim:https://www.nap.edu

National Research Council (NRC) (2011). Assessing 21st century skills: Summary of a workshop: National Academies Press. https://www.oecd.org/education/2030/E2030\%20Position\%20Paper\%20

OECD. (2018). Education at a glance 2018: OECD indicators. Paris: OECD Publishing. https://doi.org/10.1787/eag-2018-en.

Olça, M. (2015). Probleme dayalı öğrenme yönteminin öğrencilerin analitik düşünme becerileri, kavramsal anlamalart ve fene yönelik tutumlart üzerine etkileri. (Yayınlanmamış Yüksek Lisans Tezi). Dokuz Eylül Üniversitesi/Eğitim Bilimleri Enstitüsü. İzmir.

Oskay, Ö. Ö. (2007). Kimya ĕgitiminde teknoloji destekli probleme dayalı ögrrenme etkinlikleri. (Yayımlanmamış Doktora Tezi). Hacettepe Üniversitesi /Fen Bilimleri Enstitüsü, Ankara.

Ostlund, K. L. (1995). Science process skills: assessing hands on student performance. California: Addison Wesley.

Özkardeş-Tandoğan, R. (2006). Fen ĕgitiminde probleme dayalı aktif öğrenmenin öğrencilerin başarılarına ve kavram ögrenmelerine etkisi.(Yayınlanmamış Yüksek Lisans Tezi). Marmara Üniversitesi. İstanbul.

Öztürk, Z. D. (2019). Fen bilimleri dersinde probleme dayalı ögrenme yönteminin öğrencilerin akademik başarılarına ve bilimsel süreç becerilerine etkisi. (Yayımlanmamış Yüksek Lisans Tezi). Pamukkale Üniversitesi/ Eğitim Bilimleri Enstitüsü. Denizli.

Padilla, J. M. ve Okey, J. R. (1984). The effects of instruction on integrated science process skill achievement. Journal of Research in Science Teaching, 21(3), 227-287.

Pakyürek Karaöz, M. (2008). Illköğretim fen ve teknoloji dersi "Kuvvet ve Hareket" ünitesinin probleme dayalı ögrenme yaklaşımıyla öğretiminin ögrencilerin bilimsel süreç becerileri, başarıları ve tutumları üzerine etkisi.(Yayınlanmamış Yüksek Lisans Tezi). Muğla Üniversitesi/ Fen Bilimleri Enstitüsü. Muğla 
Partnership for 21st Century Skills (P21) (2003). Learning for the 21st century: A report and mile guide for 21 st century skills. https://files.eric.ed.gov/fulltext/ED480035.pdf

Pecore, J. L. (2012). Beyond beliefs: Teachers adapting problem-based learning to preexisting systems of practice. Interdisciplinary Journal of Problem-Based Learning, 7(2), 1-27.

Peterson, R. F. ve Treagust, D. F. (1998). Learning to teach primary science through problem based learning. Science Education, 82(2), 215-237.

Putri, M. K. (2017). The effect of model scientific inquiry toward science process skills viewed from scientific argumentation. Jurnal Pendidikan Fisika, 6(1), 20-26.

P21. Framework for 21st Century Learning. P21 Partnership for 21st Century Learning. http://www.p21.org/our-work/p21-framework.(18,11,2018).

Rajab A. M. (2007). The effects of problem-based learning on the self efficacy and attitudes of beginning biology majors. (Ph.D. Thesis). University of California. Los Angeles.

Sağdıç, M., Bakırcı, H. ve Boynukara, Z. (2019). Rehberli sorgulama öğretim modeline dayalı fen öğretiminin 7. sınıf öğrencilerinin bilimsel süreç becerileri üzerindeki etkisinin incelenmesi: "kuvvet ve enerji” ünitesi örneği. Yüzüncü Yll Üniversitesi Ĕgitim Fakültesi Dergisi, 16(1), 943-959.

Savery, J. R. (2006). Overview of problem-based learning: definitions and distinctions. The Interdisciplinary Journal of Problem-Based Learning, 1(1), 9-20.

Savery, J. R. ve Duffy, T. M. (1996). Problem based learning: an instructional model and its constructivist

http://www.udel.edu/soe/whitson/curriculum/files/Savery_Duffy_PBL

framework. (22.03.2016).

Ait.pdf

Serin, G. (2009). The effect of problem based learning instruction on 7th grade students' science achievement, attitude toward science and scientific process skills. (Yayınlanmamış Doktora Tezi). Orta Doğu Teknik Universitesi/Fen Bilimleri Enstitüsü. Ankara.

Shaw, A. (2008). What is 21 st century education?. Erişim: http://www.21stcenturyschools.com/

Sifoğlu, N. (2007). Illkögretim 8. sinıf fen bilgisi dersinde yaplsalcı öğrenme ve probleme dayalı ögrenme yaklaşımlarının öğrenci başarısı üzerine etkisi. (Yayımlanmamış Yüksek Lisans Tezi). Gazi Üniversitesi/ Eğitim Bilimleri Enstitüsü. Ankara.

Söyleyici, H. (2018). Probleme dayal ögrenmenin ortaokul öğrencilerinin bilimsel süreç becerilerine, tutumlarına ve başarllarına etkisinin incelenmesi: Işsk ünitesi örneği. (Yayımlanmamış Yüksek Lisans Tezi). Trakya Üniversitesi/ Fen Bilimleri Enstitüsü.

Şahbaz, Ö. ve Hamurcu, H. (2012). The effects of problem based learning and cooperative learning methods on scientific period skills of students and learning outcomes. Education Sciences (NWSA), 2(7), 734-754.

Şahin-Pekmez, E. (2000). Procedural understanding: teachers" perceptions of conceptual basis of practical work. (Yayınlanmamış Doktora Tezi). University of Durham.

Şenocak, E. ve Taşkensengil Y. (2005). Probleme dayalı öğrenme ve fen eğitiminde uygulanabilirliği. Kastamonu Ĕ̈itim Dergisi, 13(2), 359-366.

Şenyüz, G. (2008). 2000 yll fen bilgisi ve 2005 yll fen ve teknoloji dersi ögrretim programlarında yer alan bilimsel süreç becerileri kazanımlarının tespiti ve karşılaş̧ııılması.(Yayınlanmamış Yüksek Lisans Tezi). Gazi Üniversitesi. Ankara.

Tabachnick, B. G. ve Fidell, L. S. (2013). Using multivariate statistics (sixth ed.) Pearson, Boston. 
Tan, M. ve Temiz, B. K. (2003). Fen öğretiminde bilimsel süreç becerilerinin yeri ve önemi, Pamukkale Üniversitesi Eğitim Fakültesi Dergisi, 1, 89-101.

Taşkesenligil, Y., Şenocak, E. ve Sözbilir, M. (2008). Probleme dayalı öğrenme teorik temelleri. Milli Eğitim Dergisi, 177, 50-64.

Tatar, E. (2007). Probleme dayalı öğrenme yaklaşımının termodinamiğin birinci kanununu anlamaya etkisi. (Yayımlanmamış Doktora Tezi). Atatürk Üniversitesi/Fen Bilimleri Enstitüsü, Erzurum.

Tatlısu, M. (2020). Eğitsel robotik uygulamalarda probleme dayalı ögrenmenin ilkokul ögrencilerinin problem çözme becerilerine etkisi. (Yayınlanmamış Yüksek Lisans Tezi). Bursa Uludağ Üniversitesi. Bursa.

Tavukçu, K. (2006). Fen bilgisi dersinde probleme dayalı ögrenmenin öğrenme ürünlerine etkisi. (Yayımlanmamış Yüksek Lisans Tezi). Karaelmas Üniversitesi. Zonguldak.

Tekin, A. D. (2019). Probleme dayalı öğrenme yaklaşımının 7. sınıf öğrencilerinin akademik başarıları, bilimsel süreç becerileri ve motivasyonları üzerine etkisi. (Yayımlanmamış Yüksek Lisans Tezi). Marmara Üniversitesi. İstanbul.

Temel, S. ve Morgil, İ. (2007). Kimya eğitiminde laboratuvarda problem çözme uygulamasının ögrencilerin bilimsel süreç becerilerine ve mantıksal düşünme yeteneklerine etkisi. Dokuz Eylül Üniversitesi Buca Eğitim Fakültesi Dergisi, (22). Erişim: http://dergipark.gov.tr/deubefd/issue/25429/268296

Trilling, B. ve Fadel, C. (2009). 21st century skills: Learning for life in our times. San Francisco: Jossey-Bass.

Turan, S. (2009). Probleme dayalı ögrenmeye ilişkin tutumlar, ögrenme becerileri ve başarl arasındaki ilişkiler. (Yayımlanmamış Doktora Tezi). Hacettepe Üniversitesi. Ankara.

Torp, L. ve Sage, S. (1998). Problems as possibilities, problem based learning for $k-12$ education. Association for Supervision and Curriculum Development, Virginia, USA.

Tosun, C. Şenocak, E. ve Özeken Ö.F. (2013). Probleme dayalı öğrenme yönteminin üniversite öğrencilerinin kimya dersine karşı motivasyonlarına ve bilimsel süreç beceri düzeylerine etkisi. Mersin Üniversitesi Eğitim Fakültesi Dergisi, 9(3), 99-114.

Tüysüz, C., Tatar, E. ve Kuşdemir, M. (2010). Probleme dayalı öğrenmenin kimya dersinde öğrencilerin başarı ve tutumlarına etkisinin incelenmesi. Mustafa Kemal Üniversitesi Sosyal Bilimler Enstitüsü Dergisi, 7(13), 48-55.

Urtekin, A. (2012). Illkögretim 7. Sinıf ögrencilerinin kuvvet ve hareket ünitesinde kullandıklar bilimsel süreç becerilerinin bazı değişkenlerle incelenmesi. (Yayımlanmış Yüksek Lisans Tezi). Ahi Evran Üniversitesi/ Fen Bilimleri Enstitüsü. Kırşehir.

Yaman, S. (2003). Fen bilgisi ĕgitiminde probleme dayalı öğrenmenin öğrenme ürünlerine etkisi. (Yayımlanmamış Doktora Tezi). Gazi Üniversitesi/ Eğitim Bilimleri Enstitüsü. Ankara.

Yıldırım, H. (2011). Probleme dayalı ögrenme ve proje tabanl ögrenme yöntemlerinin ilkögretim ögrencilerinin başarılarına ve tutumlarına etkisi. (Yayımlanmamış Yüksek Lisans Tezi). Selçuk Üniversitesi/ Eğitim Bilimleri Enstitüsü. Konya.

Yıldırım, C. ve Can, B. (2018). Argümantasyon destekli probleme dayalı öğrenmenin öğrencilerin sorgulayıc öğrenme becerilerine etkisi. Pamukkale Üniversitesi Ĕ̆itim Fakültesi Dergisi, 44, 251-277. https://dergipark.org.tr/tr/pub/pauefd/issue/37689/425309. 
Yıldız, N. (2010). Fen eğitiminde probleme dayalı ögrenme senaryolarının çözümünde deney uygulamalarının ögrencilerin başarısına, tutumuna ve bilimsel süreç becerilerine etkisi. (Yayımlanmamış Yüksek Lisans Tezi). Marmara Üniversitesi/ Eğitim Bilimleri Enstitüsü. İstanbul.

Yıldız, T. (2017). İlköğretim fen bilimleri dersi "maddenin tanecikli yapısı" ünitesinin ögretiminde probleme dayalı ögrrenme yönteminin etkililiğinin incelenmesi. (Yayımlanmış Yüksek Lisans Tezi). Ağrı İbrahim Çeçen Üniversitesi. Ağrı.

Y1lmaz, T. (2016). Probleme dayalı ögrenme yönteminin fen konularının ögretilmesinde ortaokul 5. Sinıf öğrencilerinin akademik başarılarına ve fen bilimleri dersine yönelik tutumlarına etkisi: Işık ve ses. (Yayınlanmamış Yüksek Lisans Tezi).Bozok Üniversitesi/ Fen bilimleri Enstitüsü. Yozgat.

Yurd, M. (2007). İlköğretim 5. sinıf fen ve teknoloji dersinde probleme dayalı ögrenme yöntemi ile bil-iste-ögren stratejisi kullanilarak geliştirilen bil-iste örnekle-öğren stratejisinin ögrencilerin kavram yanılgılarının giderilmesine ve derse karşı tutumlarına etkisi. (Yayımlanmamış Yüksek Lisans Tezi). Mustafa Kemal Üniversitesi/Sosyal Bilimler Enstitüsü. Hatay.

Yurd, M. ve Olğun Ö. S. (2008). Probleme dayalı öğrenme ve bil-iste-öğren stratejisinin kavram yanılgılarının giderilmesine etkisi. Hacettepe Üniversitesi Eğitim Fakültesi Dergisi, 35, 386-396.

Yurick, K. A. (2011). Effects of problem-based learning with web-anchored instruction in nanotechnology on the science conceptual understanding, the attitude towards science, and the perception of science in society of elementary students. (Doctoral dissertation). Florida Atlantic University/Boca Raton, Florida.

Zeidan, H. A. ve Jayosi, R. M. (2015). Science process skills and attitudes toward science among Palestinian secondary school students. World Journal of Education, 5(1). http://www.sciedu.ca/journal/index.php/wje/article/view/5890.

Zimmerman, C. (2007). The development of scientific thinking skills in elementary and middle school. Development Review, (27), 172-223.

Wirkala, C. ve Kuhn, D. (2011). Problem-based learning in K-12 education: Is it effective and how does it achieve its effects. American Educational Research Journal, 48(5), 11571186.

Wagner, T. (2008). The global achievement gap: Why even our best schools don't teach the new survival skills our children need-and what we can do about it. Basic Books.

Woods, D. (1985). Problem-based learning and problem-solving, (Ed: D. Boud), ProblemBased Learning for the professions, Higher Education Research and Development Society of Australasian, Sydney, 59-66. 
EK 1. Problem Senaryoları ile 'Kuvvet ve Enerji' Ünitesinde Yer Alan Kazanımlar ve Konu/Kavramlarla Arasındaki İlişki

\begin{tabular}{|c|c|c|}
\hline Senaryo Adı & Konu & Kazanım ve ilgili kazanımın açıklamaları \\
\hline UZAY MEKİĞİ & $\begin{array}{l}\text { Kütle ve ağırlık } \\
\quad \text { ilişkisi }\end{array}$ & $\begin{array}{l}\text { 7.2.1.1 Kütleye etki eden yerçekimi kuvvetini ağırlık } \\
\text { olarak adlandırarak, ağırlığı bir kuvvet olarak tanımlar ve } \\
\text { büyüklüğ̈nü dinamometre ile ölçer. }\end{array}$ \\
\hline $\begin{array}{l}\text { ASTRONOT } \\
\text { NEDEN } \\
\text { HAFİFLEDİ? }\end{array}$ & $\begin{array}{l}\text { Kütle ve ağırlık } \\
\text { ilişkisi }\end{array}$ & 7.2.1.2 Kütle ve ağırlık kavramlarını karşılaştırır. \\
\hline İZIN SIRRI & $\begin{array}{l}\text { Kuvvet- katı basıncı } \\
\text { ilişkisi }\end{array}$ & $\begin{array}{l}\text { 7.2.2.1 katı basıncını etkileyen değişkenleri deneyerek } \\
\text { keşfeder ve bu değişkenler arasındaki ilişkiyi analiz eder. }\end{array}$ \\
\hline $\begin{array}{l}\text { DENİZ } \\
\text { KABUĞU }\end{array}$ & Sıvı basıncı ilişkisi & $\begin{array}{l}\text { 7.2.2.2. Sıvı basıncını etkileyen değişkenleri deneyerek } \\
\text { keşfeder ve bu değişkenler arasındaki ilişkiyi analiz eder. }\end{array}$ \\
\hline \multirow[t]{2}{*}{$\begin{array}{c}\text { DAĞ } \\
\text { TIRMANIŞI }\end{array}$} & \multirow[t]{2}{*}{ Gaz basıncı ilişkisi } & $\begin{array}{l}\text { a. Gazların da sıvılara benzer şekilde basınç } \\
\text { uyguladıkları vurgulanır. }\end{array}$ \\
\hline & & $\begin{array}{l}\text { b. Sıvı ve gaz basıncını etkileyen değişkenlere ve } \\
\text { matematiksel bağıntılara girilmez. }\end{array}$ \\
\hline $\begin{array}{c}\text { PİPETİN } \\
\text { İÇİNDEKİ } \\
\text { GİZEM } \\
\text { (gaz basıncı) } \\
\text { BIÇAK } \\
\text { (katı basıncı) } \\
\text { YANGIN } \\
\text { (sı1 basıncı) }\end{array}$ & $\begin{array}{l}\text { Katı, sıvı ve gaz } \\
\text { basıncının günlük } \\
\text { yaşamdaki ve } \\
\text { teknolojideki } \\
\text { uygulamaları }\end{array}$ & $\begin{array}{l}\text { 7.2.2.3 Katı, sıvı ve gazların basınç özelliklerinin günlük } \\
\text { yaşam ve teknolojideki uygulamalarına örnekler verir. }\end{array}$ \\
\hline ÇAMUR & $\begin{array}{l}\text { Kuvvet- iş- enerji } \\
\text { ilişkisi }\end{array}$ & $\begin{array}{l}\text { 7.2.3.1 Fiziksel anlamda yapılan işin, uygulanan kuvvet } \\
\text { ve alınan yolla doğru orantılı olduğunu kavrar ve birimini } \\
\text { belirtir. }\end{array}$ \\
\hline TRAMBOLIN & Enerji dönüşümleri & $\begin{array}{l}\text { 7.2.3.2 Enerjiyi iş kavramı ile ilişkilendirir, kinetik ve } \\
\text { potansiyel enerji olarak sınıflandırır. potansiyel enerji, } \\
\text { çekim potansiyel enerjisi ve esneklik potansiyel enerjisi } \\
\text { şeklinde sınıflandırır fakat matematiksel bağıntılara } \\
\text { girilmez. }\end{array}$ \\
\hline KAY KAY PİSTİ & Enerji dönüşümleri & $\begin{array}{l}\text { 7.2.4.1 Kinetik ve potansiyel enerji türlerinin birbirine } \\
\text { dönüştüğünü örneklerle açıklar ve enerjinin korunduğu } \\
\text { sonucunu çıarır. }\end{array}$ \\
\hline DENIZZ UÇAĞI & $\begin{array}{l}\text { Sürtünme kuvvetinin } \\
\text { kinetik enerji } \\
\text { üzerindeki etkisi }\end{array}$ & $\begin{array}{l}\text { 7.2.4.2 sürtünme kuvvetinin kinetik enerji üzerindeki } \\
\text { etkisini örneklerle açılar. } \\
\text { a. Sürtünme kuvvetinin kinetik enerji üzerindeki etkisinin } \\
\text { örneklendirilmesinde sürtünmeli yüzeyler, hava direnci } \\
\text { ve su direnci dikkate alınır. }\end{array}$ \\
\hline ELLER & $\begin{array}{l}\text { Sürtünme kuvvetinin } \\
\text { kinetik enerji } \\
\text { üzerindeki etkisi }\end{array}$ & $\begin{array}{l}\text { 7.2.4.2/b Sürtünen yüzeylerin 1sındı̆̆ı, basit bir deneyle } \\
\text { gösterilerek kinetik enerji kaybının ısı enerjisine } \\
\text { dönüştüğü çıkarımı yapılır. }\end{array}$ \\
\hline
\end{tabular}


EK 2. Çalışmada Kullanılan Bilimsel Araştırma Basamaklarının Yer Aldığı Örnek Bir Senaryo Çalışma Kâğıdı

\section{IZIN SIRRI}

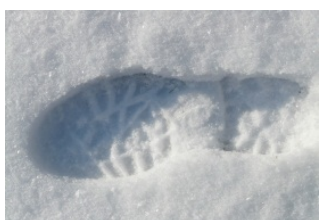

Duru ile Ekin bir haftalık kar tatilinin ardından o gün okula başlayacaklardı. Tatilin ilk günleri evde kalmaktan mutlu olmalarına rağmen birkaç gün sonra sıkılmış, arkadaşlarını özlemişlerdi. O gün okula yeni aldıkları ayakkabılarını giyerek gidecekleri için heyecanlılardı. Duru yeni alınan kar botlarını, Ekin ise gıcırgıcır hafif topuklu botlarını giydi. Her ikisinin de ayakkabı numaraları aynıydı. Okul taşıtının korna sesini duyduklarında çoktan apartmandan dışarı

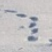

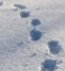
çıkmışlardı. Tüm gece boyunca kar yağdığı için her yer yine karla kaplanmıştı. Ekin önde olmasına rağmen karda rahat hareket edemiyor, her adımda ayak bileklerine kadar karın içine batarak arkasında derin izler bırakıyordu. Duru ise arkadan gelmesine rağmen kısa sürede Ekin'e yetişmişti. Oysa her ikisi de aynı kilodaydı. Ekin şaşkınlık içinde bir Duru'ya bir de her adımda karda bıraktıkları ayak izlerine baktı. İzler birbirlerinden ne kadar da farklıyd. Kendisi bu kadar zor yürüyebiliyorken Duru'nun bu kadar rahat ilerleyebilmesinin sebebi acaba ne olabilirdi?

Ekin'in merak ettiği problem nedir?*

- Ekin'in merak ettiği problemde ölçmek istediği değişken nedir? (bağımlı değişken)*

- Ekin'in merak ettiği problemde değiştirilen değişken nedir? (bağımsız değişken)*

* Ekin'in merak ettiği problemde hangi değişkenler sabit tutulur? (kontrol edilen değişken)*

* Ekin'in merak ettiği problemi çözebilmek için aşağıda verilen tabloyu uygun şekilde doldurunuz.

\begin{tabular}{|l|l|l|l|}
\hline Neler biliyorum? & Neleri öğrenmeliyim? & Nasıl/nereden öğrenenebilirim?
\end{tabular}

\begin{tabular}{|l|l|l|l|}
\hline Neler biliyorum? & Neleri oğrenmeliyim? & Nasil/nereden ögrenebilirim? & $\begin{array}{l}\text { Oğrenmedeki rolüm } \\
\text { Hangi işi } \\
\text { Nasil yaparım? }\end{array}$ \\
\hline & & & \\
\hline & & & \\
\hline
\end{tabular}

A)



Yukarıdaki hikâyede geçen problemle ilgili nasıl bir hipotez kurarsınız?*

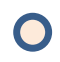

○

1).

çünkü;

2).

çünkü;

B)

GRUPÇA BELIRLENEN HIPOTEZLER** 
Grup içinde ortak olarak belirlediğiniz hipotezleri aşağıya yazınız.

1).

çünkü;

2).....

çünkü;

\section{Grupça üzerinde uzlaştığınız HIPOTEZ**}

C) Grup olarak üzerinde uzlaştığınız hipotezlerden bir tanesini aşağıya yazınız.

1)

2) çünkü



$>$ Belirlediğiniz hipotezi ispatlayabilmek için belirlediğiniz araç- gereçlerden uygun olanları seçerek bir deney tasarlayınız. Tasarladığınız deneyde hangi araç- gereçleri kullanırsınız?

$>$ Belirlediğiniz araç-gereçleri kullanarak deneyi nasıl yaparsınız?* İster yazarak ister çizimle tasarladığınız deneyi aşama aşama gösteriniz.

* Hipotezi desteklemek için deney yapıyoruz: grup olarak karar verdiğiniz deneyi yapınız.

Deneydeki değişkenleri aşağıda verilen boşluklara uygun şekilde kaydediniz.

* Sabit tutulan değişken

* Bă̆ımlı değişken

* Bağımsız değişken

$>$ Deneyde elde ettiğiniz verileri tablo, grafik v.b. halinde gösteriniz.*

\begin{tabular}{|l|l|}
\hline Bağımlı değişken & Bağımsız değişken \\
\hline & \\
\hline & \\
\hline & \\
\hline
\end{tabular}

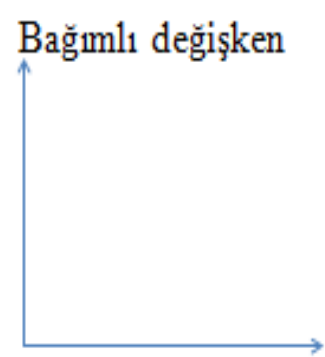

Bağımsız değişken

SONUCA VARALIM..

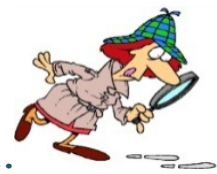

Yaptığınız deney sonucunda oluşturduğunuz tabloya/çizdiğiniz grafiğe göre nasıl bir sonuca varirsiniz?* 


\section{YORUMLAYALIM}

Hipoteziniz doğru mu :)/yoksa yanlış mı @çıktı? Elde ettiğiniz sonucu yorumlayalım...*

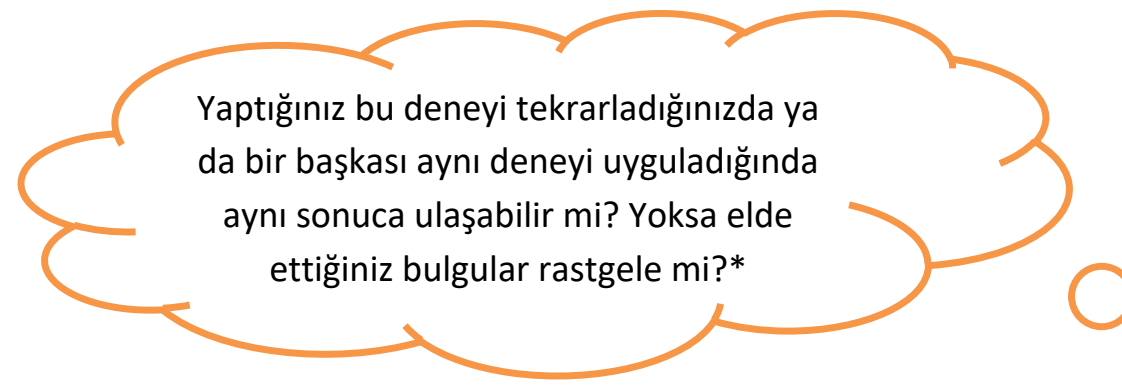

Deneyi yaparken herhangi bir zorlukla karşılaştınız mı? Eğer karşılaştıysanız karşılaştığınız zorluk neydi?*

D Sizden sonra aynı deneyi yapacaklar için tavsiyeleriniz var mı? Varsa neler?*

> Senaryoda verilen olayı ve problemi düşünün. Verilen olay, günlük yasamda karşılaştı̆ı̆ııı başka hangi olay/durum anlamanıza katkı sağlayabilir?**

\begin{tabular}{|l|l|}
\hline Neler öğrendim? & $\begin{array}{l}\text { Konu ile ilgili merak ettiğim başka soru / } \\
\text { sorularım var mı? Varsa neler? }\end{array}$ \\
\hline & \\
\hline & \\
\hline
\end{tabular}

> Yararlandığım kaynaklar:

* Can, B., Savran Gencer, A., Yıldırım, C. ve Bahtiyar, A. (2016). Fen ögretiminde probleme dayalı ögrenme (5.,6., 7. ve 8. sinıf kazanımlarına yönelik senaryo etkinlikleri). Ankara: PegemA Yayıncılık.

** Serin, G. (2009). The effect of problem based learning instruction on 7th grade students' science achievement, attitude towards science and scientificprocessskills. (Yayınlanmamış Doktora Tezi). Orta Doğu Teknik Üniversitesi/ Fen Bilimleri Enstitüsü. Ankara. 


\section{EXTENDED ABSTRACT}

\section{Introduction}

Science and technology, developing and transforming rapidly, have made it necessary to educate individuals in technology and science literacy who can keep up with this change. Preparing our new generations for the future and guiding them to be equipped for the new age is quite difficult in today's uncertainty. In such an uncertainty, it is important to become an individual who can adapt to the technology produced, make effective decisions, and have the ability to use scientific process skills effectively with problem solving skills. For this reason, it has become important to educate individuals who can reach the information they need today, use the ways of accessing information effectively, have critical thinking skills and make effective decisions and willing to be a team worker and cooperative.

Problem-based learning (PBL) is a teaching method in which the student is active during the process of structuring the information, taking into account the preliminary information, carrying out individual and group researches for the solution of the problems faced in real life, supporting the lifelong learning with effective communication (Duch, Groh, \& Allen, 2001; Hmelo-Silver, 2004; Torp \& Sage, 1998; Boud \& Feletti,1991; Peterson \& Treagust, 1998). In PBL, students apply the new knowledge they have acquired through self-regulated learning to the problem and reflect what they have learned (Tüysüz, Tatar, \& Kuşdemir, 2010).

The strategies and methods adopted in the 2018 Science curriculum foresees the conduct of courses in the learning environments that put the students at the center of learning. One of the methods used for this purpose is the PBL (MEB, 2018).

The aim of this study is to investigate the effect of PBL on students' scientific process skills by the scenarios used in the 'Force and Energy' unit.

\section{Methods}

In this study, one of the quasi-experimental models, the un-equalized pretest-posttest control group model was used. In the control group; during the process of the 'Force and Energy' unit, the lessons were processed according to the activities in the books distributed by the Ministry of Education in Turkey. In the experimental group, the PBL method was implemented during the same unit. During the study, the same teacher supervised classes, the experimental group and the control group. The participants of the study consist of 57 students who are on 7th grade in the academic year of 2017-2018 in a state middle school in Denizli. The Scientific Process Skills Test (SPST) was used as a data collection tool, developed by Aydoğdu, Tatar, Yıldiz and Buldur (2012).

A total of 13 scenarios were developed for the 'Force and Energy' unit for the application of experimental group students. While preparing the scenarios, it has been designed through situations/problems which arose and take attention of the students encountered in daily life. The problem situations chosen, have been expressed in a clear and simple language so that the students could easily understand them. In each scenario worksheet; open-ended questions were included that guided students to use the steps of scientific research method. Scenario worksheets are supported with visuals, compatible with the subject of the scenario.

In the control group, the lessons were taught without the PBL process. During the classes, the students have used the textbook which was distributed by Ministry of Education in Turkey.

\section{Results, Discussion and Conclusion}

Independent sample t-test was used to compare the pre-test and post-test scores of the experimental and control groups. The dependent sample t-test was used to compare the measurement results within each group. The result revealed that there is no significant difference of SPST between pre-test scores $(t(55)=-0,523$ and $\mathrm{p}>0,05)$. There is a significant 
difference between the posttest scores of experimental and control groups at the level of 0.05 significance ( $\mathrm{t}(55)=4,111$ and $\mathrm{p}<0.05)$. According to the research groups' posttest scores obtained from the SPST, there is a significant difference between the experimental group and the control group in favor of the experimental group. According to the findings, the experimental group students were more successful in the scientific process skills test than the control group students. This situation shows that the PBL with the scenario worksheets including the scientific research method, is effective in developing students' scientific process skills.

There are several studies that examine the change in scientific process skills where PBL is applied and have parallel results with the findings (Tavukcu, 2006; Temel \& Morgil, 2007; Oskay, 2007; Karaöz, 2008; Tatar \& Oktay, 2011; Büyükdokumac1, 2012; Aydoğdu, 2012). However, the findings obtained from this study contradict with the findings, a doctoral thesis, conducted by Serin (2009) on Grade 7 students, which PBL did not have a significant effect on scientific process skills.

Hung, Jonassen and Liu (2008) described PBL as the most innovative teaching method in the history of education. The PBL, encourages the student to think scientifically (Gallagher, Stephien, Sher, \& Workman, 1995). Science teaching through PBL enables scientific thinking and scientific process skills. Using scientific process skills, students learn how to reach a principle, law or a theory by using the necessary techniques, methods and process steps as a scientist (Can, Gencer Savran, Yıldırım, \& Bahtiyar, 2016: 8). PBL scenario worksheets, including the steps of scientific research, contribute to the development of scientific process skills in students.

It is clear that the acquisitions obtained by the PBL, the 21st century life skills and the renewed middle science curriculum (MEB, 2018) is similar in many points. Collaborative work, effective communication skills, lifelong learning skills are just a few of them. In this respect, the implementation of PBL in classes will not only provide the development of these skills, but also help individuals to gain flexible thinking skills, making effective decisions, developing their self-confidence levels, empathy skills, and social communication skills. Science literacy is important, which is actually the main purpose of the science curriculum. Therefore, students may have the ability to use research-inquiry skills actively and may develop skills to use scientific process skills effectively participating in a PBL course. 